E International

\title{
EU Air Transport Liberalisation Process, Impacts and Future Considerations
}

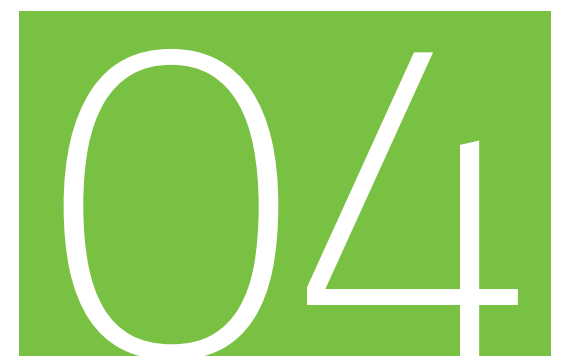

Discussion Paper 2015•04

Guillaume Burghouwt

SEO Economic Research, Amsterdam, the Netherlands

Pablo Mendes De Leon

Universiteit Leiden, the Netherlands

Jaap De Wit

Universiteit van Amsterdam, the Netherlands 


\section{EU Air Transport Liberalisation}

Process, impacts and future considerations

Discussion Paper No. 2015-04

\section{Guillaume BURGHOUWT}

SEO Economic Research, Amsterdam, the Netherlands

Pablo MENDES DE LEON

International Institute of Air and Space Law

Universiteit Leiden, the Netherlands

Jaap DE WIT

Universiteit van Amsterdam, the Netherlands

January 2015 


\section{THE INTERNATIONAL TRANSPORT FORUM}

The International Transport Forum at the OECD is an intergovernmental organisation with 54 member countries. It acts as a strategic think-tank, with the objective of helping shape the transport policy agenda on a global level and ensuring that it contributes to economic growth, environmental protection, social inclusion and the preservation of human life and well-being. The International Transport Forum organises an annual summit of Ministers along with leading representatives from industry, civil society and academia.

The International Transport Forum was created under a Declaration issued by the Council of Ministers of the ECMT (European Conference of Ministers of Transport) at its Ministerial Session in May 2006 under the legal authority of the Protocol of the ECMT, signed in Brussels on 17 October 1953, and legal instruments of the OECD.

The Members of the Forum are: Albania, Armenia, Australia, Austria, Azerbaijan, Belarus, Belgium, Bosnia and Herzegovina, Bulgaria, Canada, Chile, People's Republic of China, Croatia, Czech Republic, Denmark, Estonia, Finland, France, Former Yugoslav Republic of Macedonia, Georgia, Germany, Greece, Hungary, Iceland, India, Ireland, Italy, Japan, Korea, Latvia, Liechtenstein, Lithuania, Luxembourg, Malta, Mexico, Republic of Moldova, Montenegro, Netherlands, New Zealand, Norway, Poland, Portugal, Romania, Russian Federation, Serbia, Slovak Republic, Slovenia, Spain, Sweden, Switzerland, Turkey, Ukraine, United Kingdom and United States.

The International Transport Forum's Research Centre gathers statistics and conducts co-operative research programmes addressing all modes of transport. Its findings are widely disseminated and support policymaking in Member countries as well as contributing to the annual summit.

\section{Discussion Papers}

The International Transport Forum's Discussion Paper Series makes economic research, commissioned or carried out at its Research Centre, available to researchers and practitioners. The aim is to contribute to the understanding of the transport sector and to provide inputs to transport policy design.

ITF Discussion Papers should not be reported as representing the official views of the ITF or of its member countries. The opinions expressed and arguments employed are those of the authors.

Discussion Papers describe preliminary results or research in progress by the author(s) and are published to stimulate discussion on a broad range of issues on which the ITF works. Comments on Discussion Papers are welcomed, and may be sent to: International Transport Forum/OECD, 2 rue André-Pascal, 75775 Paris Cedex 16, France.

For further information on the Discussion Papers and other JTRC activities, please email: itf.contact@oecd.org

The Discussion Papers can be downloaded from: www.internationaltransportforum.org/jtrc/DiscussionPapers/jtrcpapers.html

The International Transport Forum's website is at: www.internationaltransportforum.org

This document and any map included herein are without prejudice to the status of or sovereignty over any territory, to the delimitation of international frontiers and boundaries and to the name of any territory, city or area. 


\section{Table of contents}

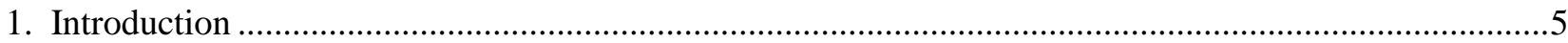

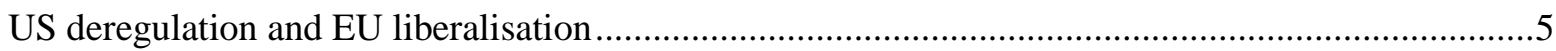

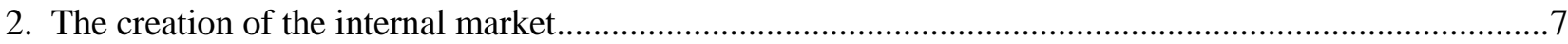

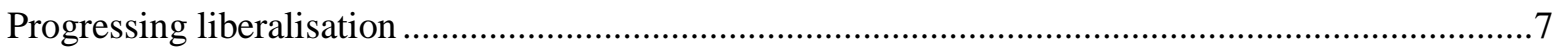

Introduction of market principles into the air transport sector of the EU ........................................

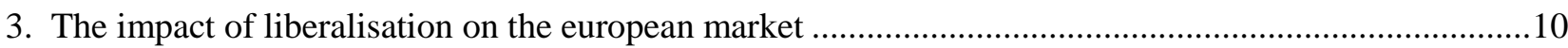

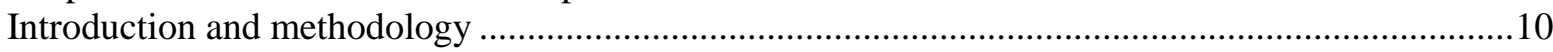

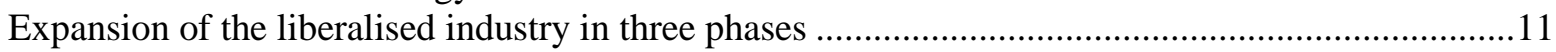

A consolidating industry with more players at the route level ......................................................14

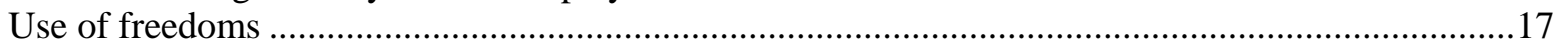

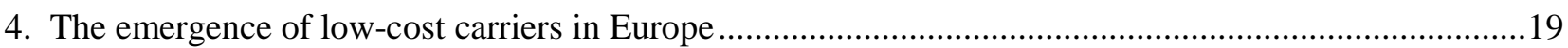

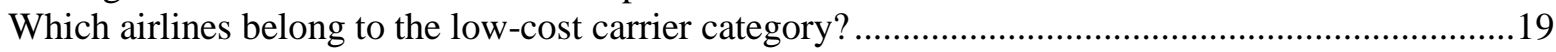

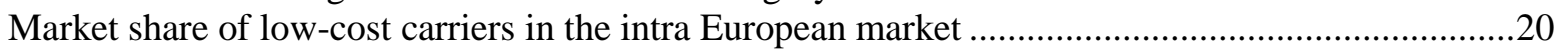

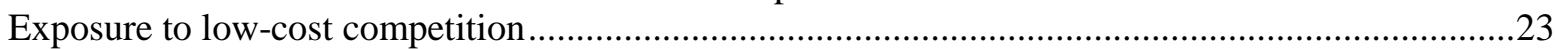

5. Development of full service network carriers in the liberalised market..................................................27

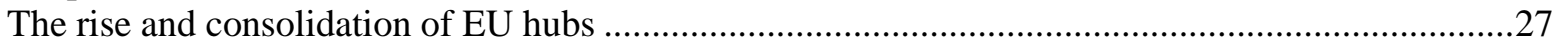

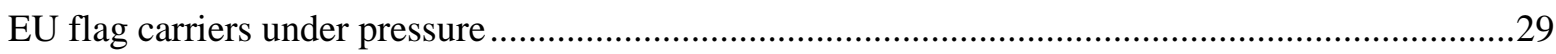

Consolidation of the European airline industry: mergers, take-overs, alliances and

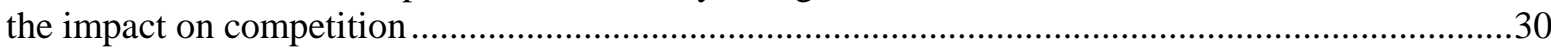

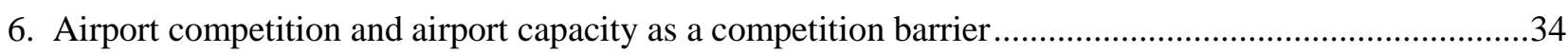

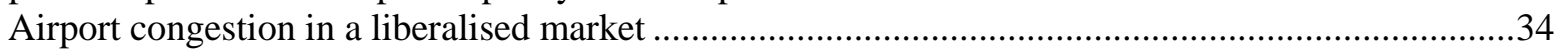

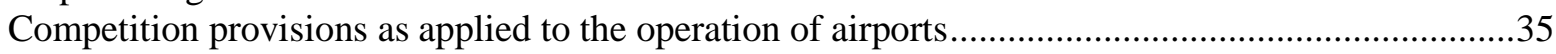

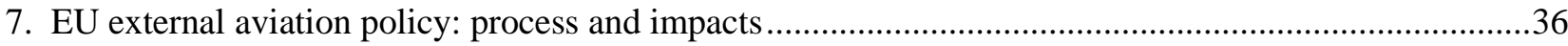

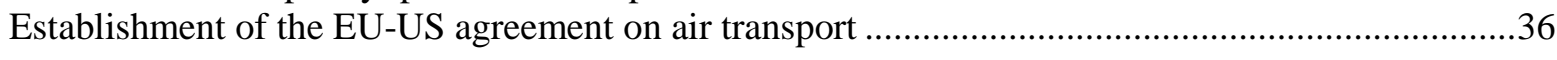

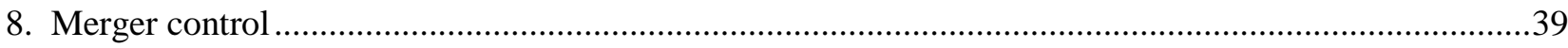

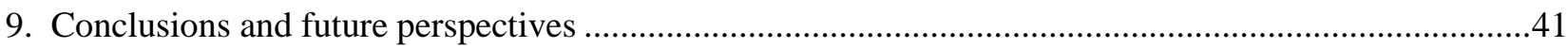

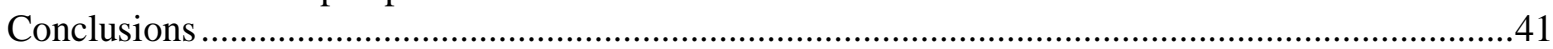

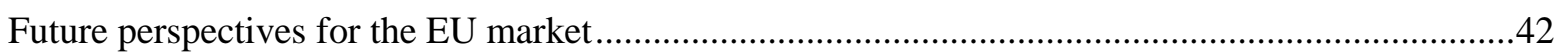

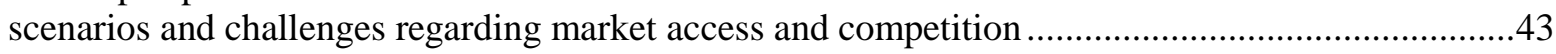

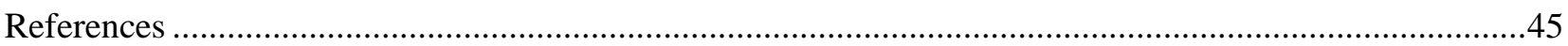

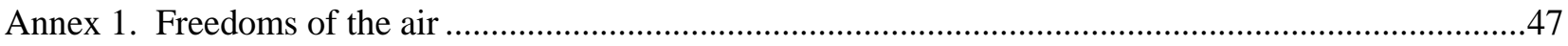

Annex 2. Low-cost airlines and years of operation as applied in this paper .............................................48

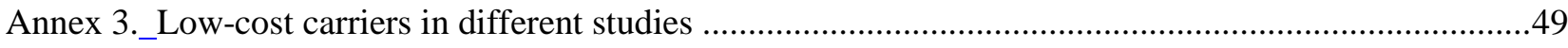

Annex 4._Comparison between bilateral and plurilateral arrangements governing the operation of international air services... 
Annex 5. The air cargo fuel charge cases. .53

Figure 1. Number of routes and number of flights within EU15+2, 1990-2013 …................................. 11

Figure 2. Number of routes and number of flights within EU15+2, 1990-2013 …................................. 12

Figure 3. Year-on-year growth of number of intra-EU15+2 scheduled flights and number of scheduled routes (airport-pairs) compared to previous year, 1990-2013 12

Figure 4. Share of different carrier types in the total number of intra-EU15+2 flights............................. 13

Figure 5. Number of scheduled carriers with services within EU15+2 and number of effective carriers,.. 15 1990-2013 15

Figure 6. Weighted number of effective carriers at the route level for intra-EU15+2 flights, 1990-2013.. 16

Figure 7. Distribution of the number of routes by number of carriers operating at the route (intra-EU15+2), 1990-2013

Figure 8. Categorisation of intra-EU15+2 services by freedom of the air for a selection of European carriers.

Figure 9. Categorisation of intra-EU15+2 services by freedom of the air for a selection of European carriers.

Figure10. Unit cost differentials for selected European FSCs and LCCs in 2012

Figure 11. Annual growth of the number of low-cost carrier intra-EU15+2 flights 1990-2013,

Figure 12. Number of low-cost flights) (A) and share of low-cost in total number of intra-EU15+2 flights (B) for a selection of originating countries, 1990-2013

Figure 13. Total number of low-cost routes (intra-EU15+2) and share of route class by number of operators, 1990-2013

Figure 14. Number of low-cost carriers and number of effective low-cost carriers (1/hhi) operating flights within EU15+2, 1990-2013

Figure 15. Percentage of routes shared by low-cost carriers and (former) flag full-service carriers .......... 25

Figure 16. Total Europe (incl. domestic) passenger yield, \$USc/RPK ..................................................... 26

Figure 17. The rise and consolidation of European hubs (EU15+2), 1990-2010 …................................. 28

Figure 18. Feeder value (number of realistic connections via the hub per direct flight) of major EU hubs in 2004 and 2014

Figure 19. Number of routes (airport-pairs) operated by (former) flag full-service carriers and share of type of routes by number of carriers, 1990-2013

Figure 20 Total number of scheduled intra-EU15+2 operations per week of the 10 largest leisure carriers 32

Figure 21. Consolidation in the European airline industry: selected mergers, take-overs and bankruptcies of legacy carriers. 33

Figure 22.. Airport congestion according to Eurocontrol's scenario C 34 


\section{Introduction}

\section{US deregulation and EU liberalisation}

The stepwise liberalisation of the EU internal aviation market resulted in 1993 in an open internal market that generated a series of supply side responses, which are partly comparable with the changes demonstrated in the deregulated US domestic air transport market.

However, the starting point was quite different between these two markets. For example, until the deregulation in 1978, US legacy carriers operated a domestic crisscross network whereas the two flag carriers, Pan Am and TWA operated at various US gateways in stand-alone international networks based on the bilateral air service agreements concluded between the US and other states. After the deregulation, domestic major carriers transformed their crisscross domestic networks into radial hub and spoke networks (except the Delta hub at Atlanta that already existed before the deregulation). The domestic hubs in these networks also became the launching platforms for international operations when these domestic major carriers started to use their domestic feed for international operations. All in all, the former domestic major carriers became the new flag carriers in international markets, whereas the former two flag carriers went bankrupt due to the lack of domestic feed in order to adequately compete with these new internationally operating airlines.

In Europe, the liberalisation started under very different socio-economic and (aero)political circumstances. In each EU-member state, a state-owned national airline already operated a starburst international and intercontinental network at its national home base. However, most of these networks were not hub-and-spoke networks in a strict sense as temporal coordination of the flight schedule was lacking at those home bases (Burghouwt \& De Wit 2005). The national airline was the designated carrier for the bilateral air service agreements concluded between that individual state and other states inside and outside Europe. The process of stepwise liberalisation of the internal market was simultaneously combined with an increasing number of bilateral open skies agreements and separately granted antitrust immunity on an ad hoc basis between individual EU member states and the US. As a result, as Burghouwt \& De Wit (2005) and Burghouwt (2007) showed, the national 'flag' carriers developed their radial networks and national home bases in the 1990s into fully fledged hub and spoke systems with intensified wave-systems, leading to quickly rising hub connectivity levels. The rise of the hub-and-spoke systems in Europe also enabled the emergence of intercontinental multi-hub systems with alliance partners in the US, leading to 'dog bone' networks, which strongly stimulated demand in the behind and beyond markets of these coupled hubs. An important difference remained between US major carriers and EU national airlines. National airlines in the EU continued to focus only on national and international routes in a hub and spoke network from their national home base, without developing new hubs elsewhere in Europe. However, US carriers started to operate at various hubs covering the entire US domestic market after the deregulation. 
Furthermore, in the European market another type of business model was applied successfully that hardly existed in the US market: the non-scheduled holiday charter operator providing total seat capacity of their aircraft to tour operators for resale to passengers either booking their flight under Advance Booking Charter (ABC) conditions in the North Atlantic market or Inclusive Tour Charter (ITC) conditions in the Mediterranean holiday market. The success of this business model in Europe was reflected in the expectations that unscheduled operations would equal the scheduled international traffic in Europe by 1975/76. (Doganis, 1973). The regulatory conditions within which non-scheduled carriers could operate varied from country to country, ranging from prior authorization of incoming flights to special air service licenses. After the liberalisation, inclusive tours continued to be offered by tour operators after the transformation of the charter carriers into so-called leisure airlines. This was due to the third package of liberalisation measures by which the distinction between scheduled and non-scheduled operations became superfluous after the introduction of the concept of community air carrier (Council Regulation (EEC) No 2407/92) as well as the removal of restrictions on market entry, capacity, frequency and pricing (Council Regulation (EEC) No 2408/92 and No 2409/92). This enabled the former charter operators to convert their air services to the schedule mode and to transform into scheduled leisure airlines. The more or less comparable type of operation in the US, the so-called supplemental carrier, only played a very limited role in the US market. However more recently the US low-cost carrier Allegiant Air successfully started to sell an unbundled version of the traditional package tour product by a self-packaging formula for accommodations and air trips separately.

Taking into account the unique characteristics of the European air transport market, this paper will provide an overview of the process and impacts of European air transport liberalisation. We will start with a description of the creation and liberalisation of the internal aviation market. Then, we will shift our focus to the impact of intra-EU liberalisation during the period 1990-2014, will touch upon the external dimension of EU liberalisation and discuss the issue of merger control within the context of consolidation in the liberalized EU air transport industry. Finally, we conclude with a discussion of the future perspective for the liberalized EU air transport industry. 


\section{The creation of the internal market}

\section{Progressing liberalisation}

Until the entry into force of the EU internal air transport market regulations on 1 January 1993, intraEU routes were to a large extent 'monopolised' by the EU flag carriers such as British Airways, Air France, Lufthansa, Alitalia, Iberia, KLM and so forth who were operating their intra-European network under bilateral air services agreements concluded by their respective States. Hence, Air France was allowed to fly, by virtue of those agreements, from Paris, and other points in France, to bilaterally agreed points in the UK, but not from, for instance, Rome to Madrid. As a consequence, such carriers were, on the one hand, limited as to the choice of their operations because they were generally restricted to markets governed by bilateral regimes, that is, in the above case, the market consisting of points between France and the UK. On the other hand, they were also protected by their governments who decided which level of 'market freedom' should be available for 'their' carriers in order to survive the interplay of market forces. Thus, if need be, such bilateral arrangements were adjusted for the benefit of the designated carrier or carriers of either side. In short, bilateral air services agreements regulated, and, in many cases, restricted market entry, and market opportunities, for the benefit of these traditional 'flag' carriers. As a result, the number of effective competitors at the route level was low in the early nineties and the share of single carrier routes even further increased until 1995 (see figure 7).

Such a scheme was not in line with the EU principles proceeding from an "open market with free competition" (see Article 119 of the Treaty on the Functioning of the EU). That is why, at the end of the 1980 s, the barriers for the operation of intra-EU flights were gradually removed, stimulated thereto by the UK and the Netherlands proclaiming liberal aviation policies in the - then - EEC.

However, for commercial reasons, the incumbent 'flag' carriers did not, and have not made full use till today from the freedoms afforded to them: Iberia's operations are still limited to routes which start and end in Spain, and Lufthansa's network is based on points from and to Germany. Figure 8 shows that the use of the freedoms by the 'flag' carriers is limited. This is in sharp contrast with the segment of low-cost carriers, which makes extensive use of the opportunities that exist in the liberalised market (see the Emergence of low-cost carriers in Europe section).

\section{Introduction of market principles into the air transport sector of the EU}

The above liberalisation measures did not only introduce the freedom for an EU air carrier as defined under relevant EU law to operate any route within the EU, but also removed restrictions as to capacity, that is, the equipment an EU air carrier so designated is allowed to use on the mentioned operations and the frequencies of such operations, as well as the freedom to set prices in accordance with the market rather than government dictated - as was the case in the aforementioned bilateral agreements - principles. At the same time, the distinction between scheduled and non-scheduled services has been largely removed so as to enable all types of air carriers holding EU operating licences, as explained in the next section, to provide services anywhere within the EU internal market, in accordance with demand. 
The new freedoms were principally exploited by the newcomers in the second half of the 1990s such as EasyJet and Ryanair, as well as other (low cost) carriers and former charter carriers. Their route network is principally different from that of the incumbent flag carriers (see the Emergence of low-cost carriers in Europe section).

\section{The internal dimension}

A topical question concerns the definition of an EU air carrier as the above freedoms for the operation of intra-EU services are exclusively granted to them.

In short, an EU air carrier is a carrier which:

- Is majority, that is, more than $50 \%$, owned by EU States or their nationals, in terms of shareholding;

- Effectively controlled by EU States or their nationals, that is, such persons must exercise a decisive influence on the management of the EU air carrier;

- Has its principal place of business in an EU State, which State has granted a valid operating license to the air carrier in question.

The topicality of the above conditions is demonstrated by, among others, the investments made by the Arab carrier Etihad into airberlin, Alitalia and other European carriers. Consequently, the EU Commission must examine whether these air carriers can still be qualified as "EU air carriers" in order to protect the values of the internal EU market, which values are reserved for EU air carriers only.

These examinations are all the more important as the external/international air transport market is not liberalised but still governed by bilateral air services agreements, which can be very restrictive in terms of market access and market behaviour, but may also have a far more liberal character as exemplified by so called 'Open Skies' agreements including the EU-US agreement on air transport (see the EU external aviation policy section).

\section{The external dimension}

As a consequence of decisions made by the Court of Justice of the EU in 2002 in the so called 'Open Skies' cases, the EU air carrier clause, also known as the Community air carrier clause, had, to be implemented in bilateral air services agreements concluded between the EU States and third States in order to guarantee and implement the Freedom of Establishment in this sector. In practice, KLM should be entitled to fly not only between Amsterdam and points in Brazil, but also from, for instance, Madrid, if it has an 'establishment' there. In the summer of 2014, over 1000 out of about 3000 of such bilateral agreements encompass the EU air carrier clause instead of the 'traditional' air carrier clause based on the 'true' nationality of the air carrier, hence, the Dutch nationality of, for instance, KLM.

Obviously, this EU air carrier clause helps to secure the operation of traffic rights by EU carriers whose nationality expressed in terms of ownership and control of the undertaking, that is, the air carrier, in question, is 'affected' by a merger or takeover, such as KLM, Swiss or Austrian Airlines. On the other hand, it has not contributed to the provision of 'off-line' air services by EU air carriers as such 'off-line' operations, that is, operations carried out outside the principal hub and home country of the carrier, for instance, the operation of flights by Air France from Rome to New Delhi, are not lucrative undertakings. 


\section{The application of competition to the air transport market}

The internal air transport market rules were supplemented by implementing rules for the air transport sector, including exemptions from the scope of the EU competition rules. As bilateral provisions governing the air services operated by the former national air carriers, which had now become EU air carriers were superseded in 1993 by the internal air transport regime, the newly acquired freedoms of the undertakings, that is, the EU air carriers came under the supervision of the EU Competition authorities, that is, the EU Commission. This body has vigorously applied and enforced these rules, which principally address concerted actions conducted by EU air carriers, and abuses of dominant positions by them.

The EU competition rules also include rules on State aid, which have been, applied myriad times to EU air carriers in the 1990s and in the first decade of the 21st century, and which have contributed to, among others, the disappearance of former flag carriers such as the Belgium carrier Sabena and Swiss Air. The EU State aid rules are now applied to airports, which also have to behave as 'commercial undertakings' and which are, hence, not allowed to favour certain carriers, as to which see the well know CharleroiRyanair case (in the Competition Provisions as applied to the Operation of an Airport section).

In the context of the enforcement of the EU competition regime, EU and non-EU air carriers whose operations affect the functioning of the EU internal market are also subject to the EU Merger Regulations. In the past ten years, the EU authorities, namely, the Commission and the Court of Justice of the EU have scrutinised mergers concerning, among others, Air France-KLM, Lufthansa-Swiss and Lufthansa-Austrian Airlines, and British Airways-Iberia, and subjected the approval of them to conditions which are concisely addressed in the Merger Control section. The envisaged merger between Ryanair and Aer Lingus has not been sanctioned as Ryanair is supposed to become too dominant on certain routes when it absorbs Aer Lingus, especially on the Dublin London route. The same happened to the Greek carriers Aegean and Olympic in the years 2012 and 2013 as the merged entity was also perceived to become too dominant on certain domestic and international routes. The last mentioned merger was eventually approved by the EU Commission on 9 October 2013. The Commission argued that the merged entity would create the conditions for the establishment of a sustainable and competitive Greek carrier, capable of supporting Greek Tourism and the local economy.

Next to the application of competition rules, EU and other air carriers flying into and from EU airports, are also dependent on the availability of slots and must meet safety and environmental conditions. Congestion at airports as a consequence of the increase of air traffic, coupled with environmental concerns, has led to a shortage of slots. This phenomenon has sometimes impeded market access for new entrants as the traditional carriers, including former flag carriers, jealously kept their slots under 'grandfather rights' regimes. The EU Commission is addressing this subject, which also raises competition related concerns. Slot trading could remedy current market entry problems. 


\section{The impact of liberalisation on the European market}

\section{Introduction and methodology}

The creation and opening up of the EU internal market has had substantial impacts on the structure of the market, entry, competition, consolidation and rise of new business models. Yet, although the impacts of European air transport liberalisation have received considerable attention during the early period of the internal, liberalized market (Button 2001; CAA 1995, 1998; Doganis 1994; Graham 1998; Morrell 1998; Reynolds-Feighan 1995; Williams 1994, 2002) as well as for separate geographical markets (Belén Rey 2003; Thompson 2002), its longer term overall impact has been studied much less intensively, except perhaps for Dobruszkes (2009) who analyses changes in competition levels and use of freedoms within the EU over the 1991-2005 period. In the following sections, we will contribute to the understanding of the long-term impact of EU liberalisation by providing an analysis of the supply side developments in the common EU aviation market since the beginning of liberalisation over a 24-year period.

Based on time series OAG airline schedules database covering the years 1990-2013 for a representative week in each year ${ }^{1}$, this section will provide an overview of the development of a number of key indicators between 1990 and 2013 that together give insight into the longer term impacts of the creation and liberalisation of the internal European air transport market: airline output, number of carriers in the market, number of carriers at the route level, the use of the 'freedoms of the air', rise and impact of the lowcost carrier, the position of the (former) 'flag' full service carrier and airline industry consolidation. As the year 2000 was lacking in our time series data, we have estimated the 2000 results by means of interpolation. Only unique, direct scheduled flights have been included in the analysis. Indirect connections, code-shared duplicating flight options and non-scheduled operations have not been taken into account.

The analysis in the following sections will focus on the direct liberalisation impacts on the air transport market itself. The well-known sequence of liberalisation $\rightarrow$ new and better air services $\rightarrow$ air traffic growth $\rightarrow$ economic growth $\rightarrow$ new employment (Intervistas, 2006) is outside the scope of this paper.

As to make consistent comparisons over the various years, we have chosen a stable set of countries as the spatial base for our analysis: the EU15+2 area, which consists of the 15 countries that in May 1994 composed the European Union before the entry of the ten accession countries. To this region, we have added Switzerland and Norway. In addition, we have categorized the airlines operating within the EU15+2 areas into different business models: the (former) 'flag' full service carriers (flag carriers), low-cost carriers, leisure carriers, other carriers (regionals, hybrids, air taxi's etc.) and extra-EU15+2 carriers. Admittedly, such a categorization -in particular over a prolonged period of time- always brings with it arbitrary choices as business models in the airline industry are dynamic and increasingly hybrid. These considerations should be born in mind when interpreting the results of our analysis. The categorization of low-cost carriers will be discussed in more detail in the Which Airlines Belong to the Low-Cost Carrier Category section.

\footnotetext{
13 rd week of July of each year
} 
Expansion of the liberalised industry in three phases

One of the most noticeable impacts of liberalisation has been the expansion of the European airline industry. Not tied to the bilateral air service agreements anymore, European carriers initiated new services: airlines increased frequencies on existing routes, new routes were opened and new operators entered the market. The resulting increase in service levels and lower airfares stimulated demand, leading to further output expansion. Between 1990 and 2013, the number of intra-EU15+2 flights increased by 80\%, while the number of routes increased by $138 \%$ over the same period. Regarding the expansion of the market, we can roughly distinguish between three phases.

\section{Phase 1: the early years}

The first phase is the 1990-1993 period, started with the 2nd package of liberalisation measures in November 1990 until the 3rd package of liberalisation measures took effect in 1993. The second package gave all EU carriers the opportunity to carry unlimited 3rd and 4th freedom traffic, but still with substantial restrictions in terms of multiple designation and 5th, 7th freedom and cabotage ${ }^{2}$. Also influenced by the economic downturn in the early 1990s, this period is characterized by relatively low growth rates in frequencies and routes compared to the second half of the 1990s (Figure 3) Average route frequencies remained stable at 16 flights per week (Figure 1and 2) and. At the route level, the number of effective carriers did not yet increase (Figure 6).

Figure 1. Number of routes and number of flights within EU15+2, 1990-2013

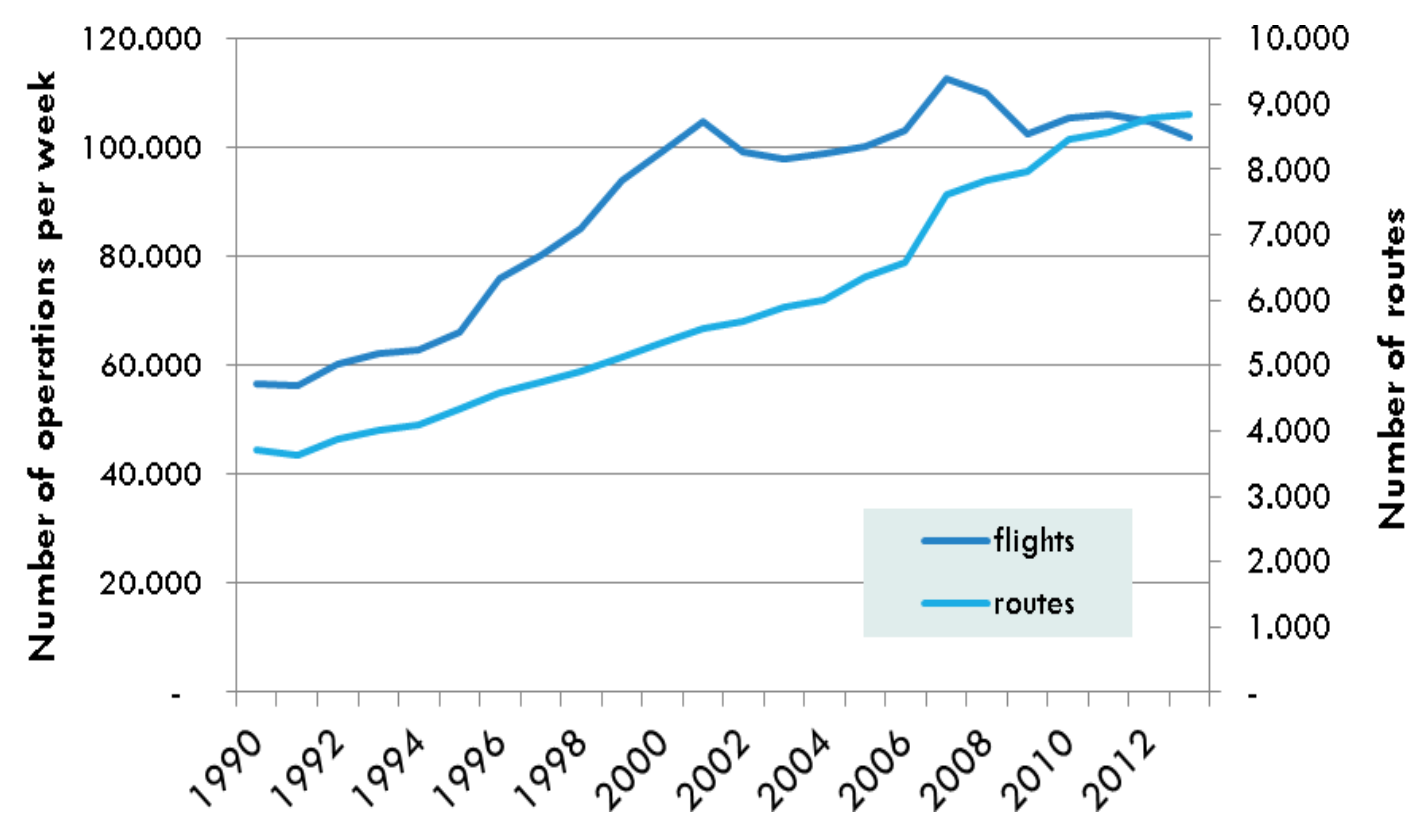

Source: OAG; analysis by authors

2 See Annex A for an overview of traffic rights

G. Burghouwt, et al. — Discussion Paper 2015-04 - (C) OECD/ITF 2015 
Figure 2. Number of routes and number of flights within EU15+2, 1990-2013

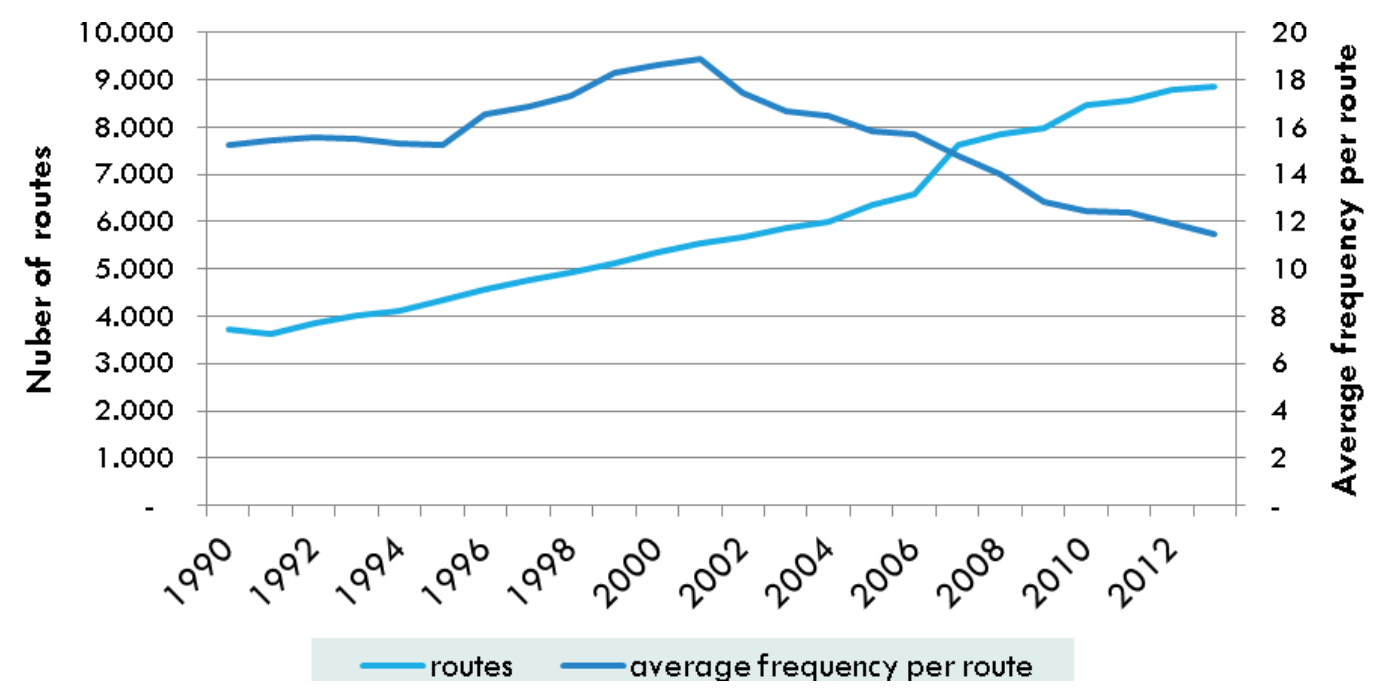

Figure 3. Year-on-year growth of number of intra-EU15+2 scheduled flights and number of scheduled routes (airport-pairs) compared to previous year, 1990-2013

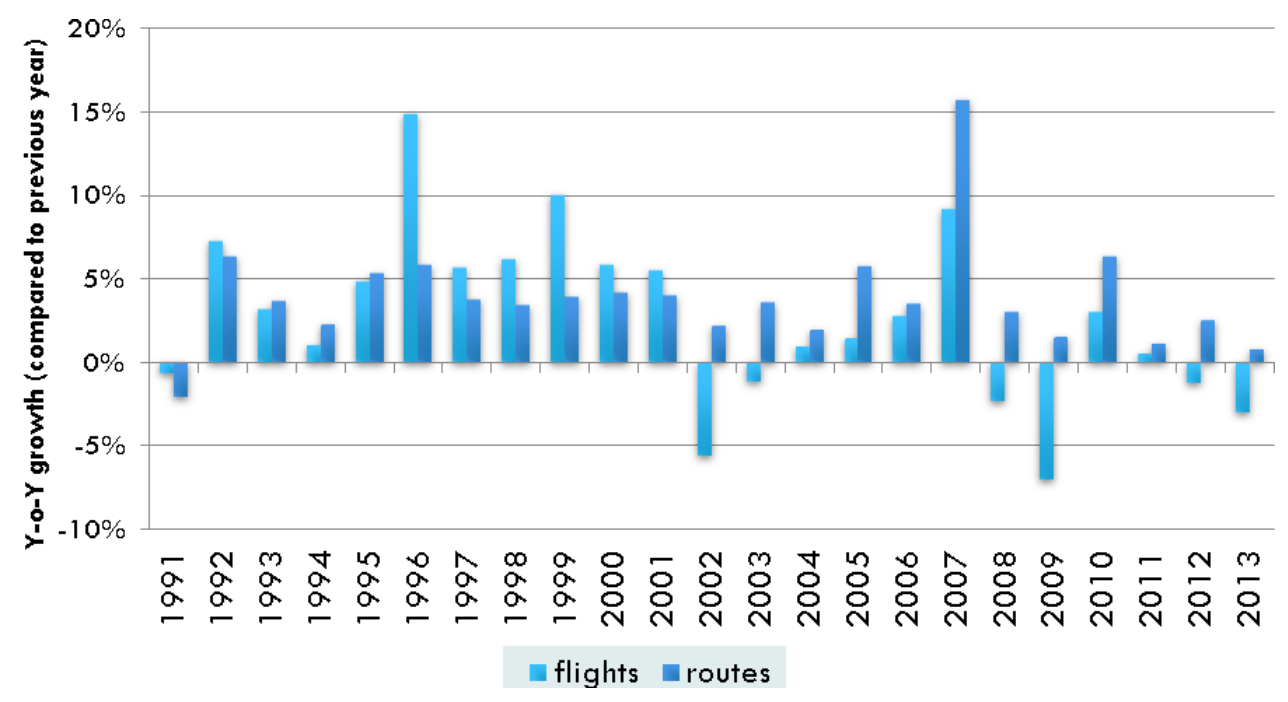

Source: OAG; analysis by authors

Phase 2: growth of the flag carrier and hub-systems (1994-2000)

The second phase between 1994 and 2000 is characterized by a rapid growth in the number of flights relative to the increase in the number of routes, resulting in an increasing average weekly frequency per route (Figure 1 and 2). 
The higher average frequencies per route were partly the result of the intensification and adoption of hub-and-spoke networks by the (former) flag full-service carriers during the second half of the 1990s. Airlines such as Lufthansa, Swiss Air and KLM intensified the wave-systems at their hubs, while other flag carriers such as Iberia, Air France and Alitalia started to develop hub operations at their national airports by developing planned connection waves (see also the section on the Rise of EU hubs). Both the intensification of the wave-systems of the flag carriers and the establishment of such systems led to higher frequencies at the feeder routes into the hub, benefitting from the advantageous economic conditions during the second half of the 1990s. The share of these carriers in the intra-EU15+2 markets increased substantially during the second phase (Figure 4).

Moreover, (new) carriers took advantage of the opportunities in the liberalized market to break the monopoly of the flag carriers. The share of monopoly and duopoly routes went down during the second phase, whereas the share of routes with three carriers or more increased (Figure7). The increased effective competition at the route level is also demonstrated after weighting for the individual market shares of the competitors per route (Figure 6). Yet, as cabotage only became fully possible as of April 1997, domestic routes inside individual member states remained less sensitive to these increases in competition till 1997.

In sum, the second half of the 1990s offered favorable economic and regulatory conditions for the rise of the flag carriers in Europe, operating hub-and-spoke networks centered on their national airports. On the one hand, economic growth stimulated aviation demand, fuel prices were declining and many routes were still underserved. On the other hand, the third package gave them unlimited 3rd, 4th, 5th, 6th and 7th Freedom rights, and, as from 1 April 1997, also 8th and 9th ('cabotage') Freedom rights (see Annex 1), which was exactly what they needed to build up their national hub operations. At the same time a few lowcost carriers were testing the market and slowly took off.

Figure 4. Share of different carrier types in the total number of intra-EU15+2 flights $^{3}$

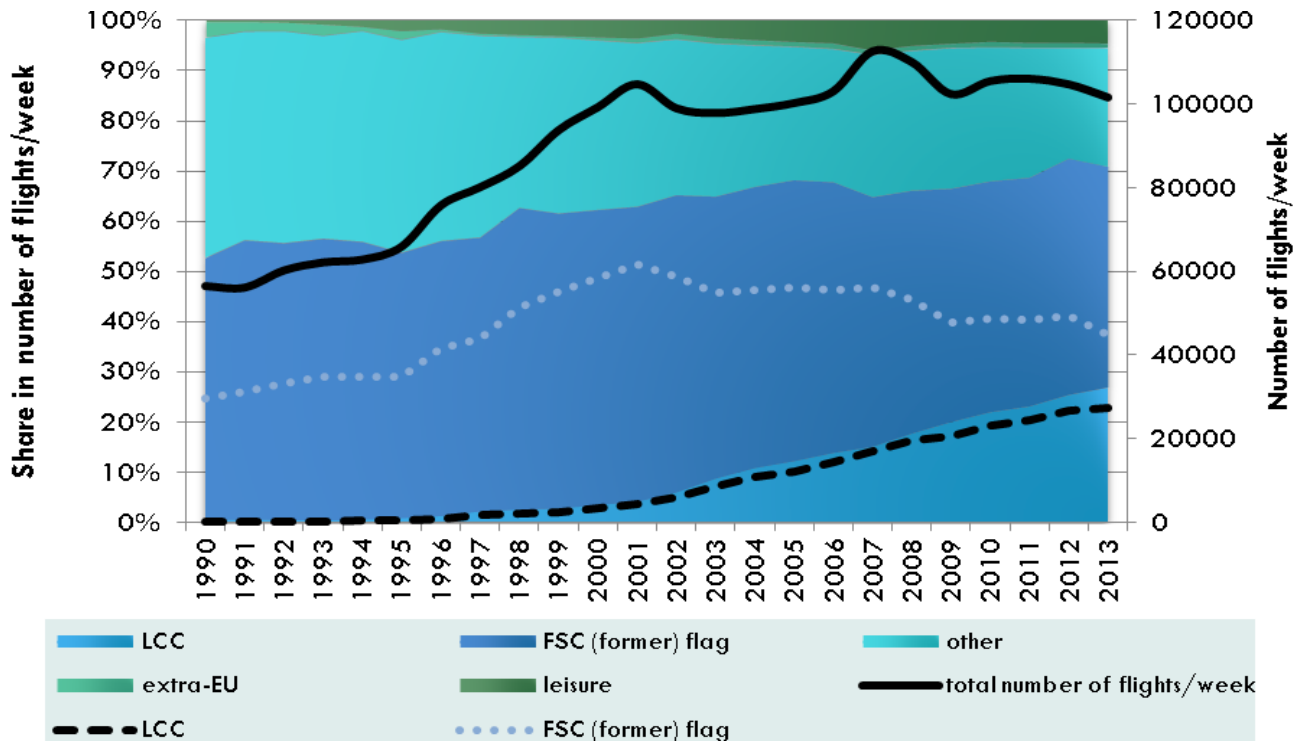

Source: OAG; analysis by authors

3 Note that that the sharp 2006-2007 increase is -apart from network expansion by Ryanair- the result of leisure non-scheduled carriers such as First Choice Airways, MyTravel and Thomsonfly to start (semi-) scheduled operations to holiday destinations and as such included in the OAG-data. Hence, the capacity was already in the market but was not yet labeled as scheduled.

G. Burghouwt, et al. — Discussion Paper 2015-04 — @ OECD/ITF 2015 


\section{Phase 3: the era of the low-cost carrier (2001-2013)}

After a continuous increase in average frequency per route during the second phase, in 2000 a third phase started, which marks a continuous decline in the average frequency per flight until 2013, as well as a stabilization of the total number of intra-EU15+2 flights (Figure 1), but a continuous expansion of the number of routes. As of 2006, the number of effective carriers at the route level starts to stabilize after a long period of continuous growth (Figure 1).

The full access to the EU aviation market (including unrestricted cabotage rights as of 1 April 1997) gave low-cost carriers the opportunity to fully penetrate the European market, including the Member States' domestic markets. They took advantage of the opportunity to establish an ever increasing number of crew and aircraft bases all over Europe, whereas the flag carriers remained designated to their national home bases. This was for operational reasons of hubbing as well as aeropolitical reasons of nationally restricted traffic rights with regard to intercontinental routes. Facilitated by the introduction of direct Internet booking platforms, low-cost carriers started to gain market share quickly at of the end of the 1990s (see also Figure 4). Yet, their business model is essentially different from that of the full-service network carriers: sufficient route density is not created through complex hub-and-spoke operations, but by serving an extended catchment area by using a low unit cost base to charge low fares, generate new market demand and serving routes at a lower frequency than the full service carriers. Hence, the growth of the low-cost carrier segment took place by means of quick expansion of the number of routes but at relatively low -and over timedeclining average frequencies per route. The declining average frequencies at the route level may increasingly reflect the problem of starting new routes with a sufficient route density to at least operate a once a week frequency. This may indicate a saturation of viable secondary routes, as argued by De Wit and Zuidberg (2012). We will get back to the growth limits of the low-cost carrier model in the liberalized EU market in the Emergence of Low-Cost Carriers in Europe section.

In addition, the growth in the number of flights and routes served by the 'flag' carriers stagnated/became negative as of 2000, resulting in a substantially declining share in the number of intraEU15+2 flights between 2000 and 2013 (Figure 4). First of all, the declining share and stagnation/negative absolute growth of the (former) flag carriers such as Lufthansa and Air France can be explained by the consolidation in the European airline industry, which from 2000 (with the bankruptcies of Sabena and Swiss Air) also started to affect the flag carriers (see Figure 21). Secondly, the 'flag' carriers have been rationalizing their networks since the beginning of the century in response to increasing competition from both inside the EU market (low-cost carriers), outside the EU market (Turkey and the Gulf) and adverse economic conditions (rising fuel prices and economic downturns). Some airline bases have been de-hubbed by their respective home carriers, such as Milan Malpensa (Alitalia), Barcelona (Iberia) or have been drastically downsized (Copenhagen by SAS) (see also the Development of Full Service Network Carriers section). Thirdly, the stabilizing number of frequencies served by the flag carriers may also indicate a certain saturation of the continental market of the EU hubs.

Hence, from 2000 on, the quickly growing low-cost carrier segment in combination with a decline of the (former) flag full-service carrier share resulted in further growth of the intra-EU route network but also in stagnating frequency growth and declining average route frequencies in this third post-liberalisation phase.

\section{A consolidating industry with more players at the route level}

After deregulation of the US domestic market, a first phase of new entry was followed by a phase of industry consolidation, characterized by take-overs, mergers and bankruptcies. Morrison \& Winston (1995) showed that the number of effective competitors ${ }^{4}$ in the US domestic airline industry increased rapidly after

$4 \quad 1 / \mathrm{hhi}$ 
1978, to fall substantially again after 1987 and reach a low, stable level. Do we see a similar pattern for the liberalized EU air transport market?

According to CAA $(1995 ; 1998)$, the EU market saw a $40 \%$ increase in the number of carriers operating in the market between 1986 and 1990. From 1990 on, according to our OAG database on scheduled services, the number of effective carriers in the intra-EU15+2 market has been -apart from some ups and downs- been decreasing from over 200 in 1990 to less than 130 in 2013. In other words, the European airline industry has been consolidating since the early 1990s, although this consolidation trend seems to have accelerated since the start of the economic crisis in 2003 (Figure 5). We expect the consolidation trend to be more severe in reality, as we have only looked at the number of operators with unique codes.

\section{Figure 5. Number of scheduled and effectives carriers with services within EU15+2 and number of effective carriers $^{5}, 1990-2013$}

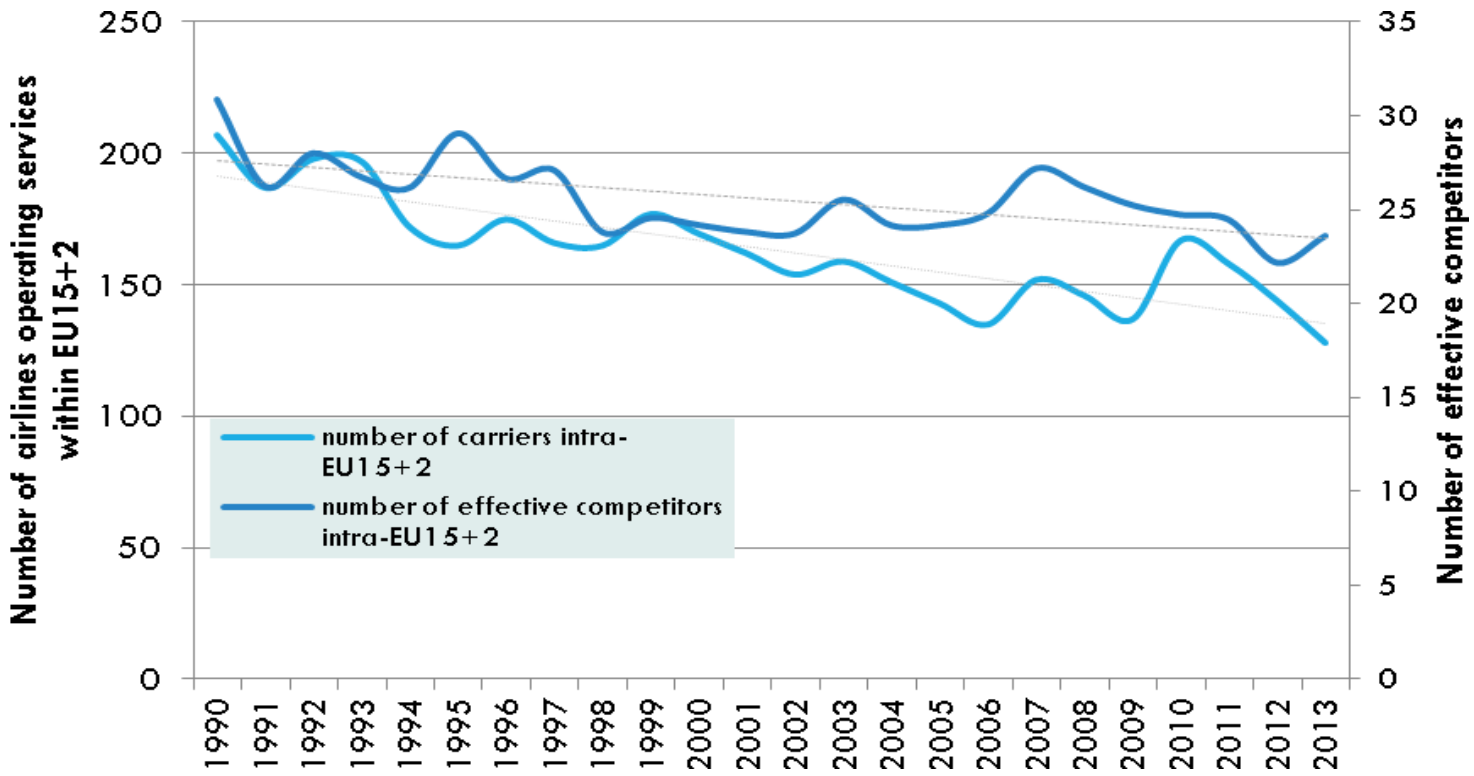

Source: OAG; analysis by authors

Fewer effective players at the EU market level do not necessarily result in decreased airline competition, for it is at the route level that airlines compete head to head according to the relevant market approach of the European Commission. In the EU15+2, the declining number of effective players at industry level has not resulted in a decrease in the number of effective players at route level. On the contrary, the number of carriers at the route level has been on the rise since 1994, when the third package of liberalisation measures came into force (Figure 6). Since 2007, the average number of effective carriers at the route level has stabilized around 1.45. The result for the EU-market is more or less in line with the developments following industry consolidation in the US domestic market: sharply rising concentration levels after 1987 did not result into more concentration at the route level (Morrison \& Winston 1995) and concentration levels were still much lower than before deregulation.

$5 \quad$ Number of effective carriers: $1 / \mathrm{hhi}$ at industry level. Input to the HHI are total number of weekly flights

G. Burghouwt, et al. — Discussion Paper 2015-04 — C OECD/ITF 2015 
Figure 6. Weighted number of effective carriers at the route level for intra-EU15+2 flights, 1990-2013

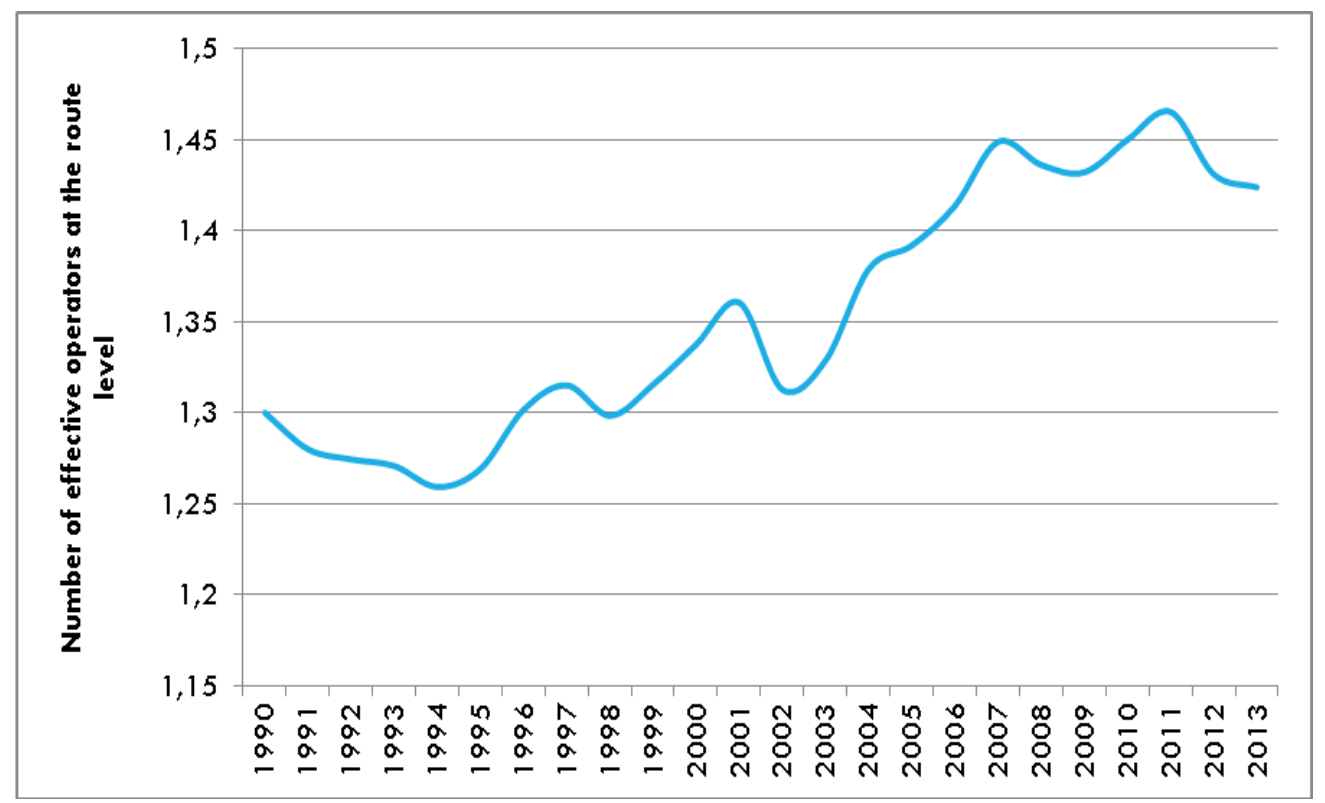

Source: OAG; analysis by authors

The increasing number of effective carriers at the route level is not fully mirrored by the development of the share of single carrier and multi-carrier routes (Figure 7): the share of single carrier routes within the EU15+2 decreased during the second phase (1993-2000) to increase again after 2000. Over the entire 24year period of analysis, the share of single carrier routes has remained stable at $26 \%$. In absolute terms, the number of single carrier and multi-carrier routes increased at an equal pace. However, such an analysis does not take into account the output of various carriers at the route level, nor does it take into account the relative weight of the routes ${ }^{7}$ within the entire intra-EU15+2 aviation network. A weighted analysis using a concentration ratio as has been done in (Figure 6)Error! Reference source not found. then reveals the ncrease in the number of effective carriers at the route level.

$6 \quad$ Number of effective carriers: $1 / \mathrm{HHI}$ at the individual route level weighted by the share of the route in total number of flights in the EU15+2 market. Input to the HHI are number of weekly frequencies by a published carrier at the route level. In terms of the share of the route in total number of intra-EU15+2 flights 
Figure 7. Number of routes and number of carriers operating at the route level (intra-EU15+2), 1990-2013 ${ }^{8}$

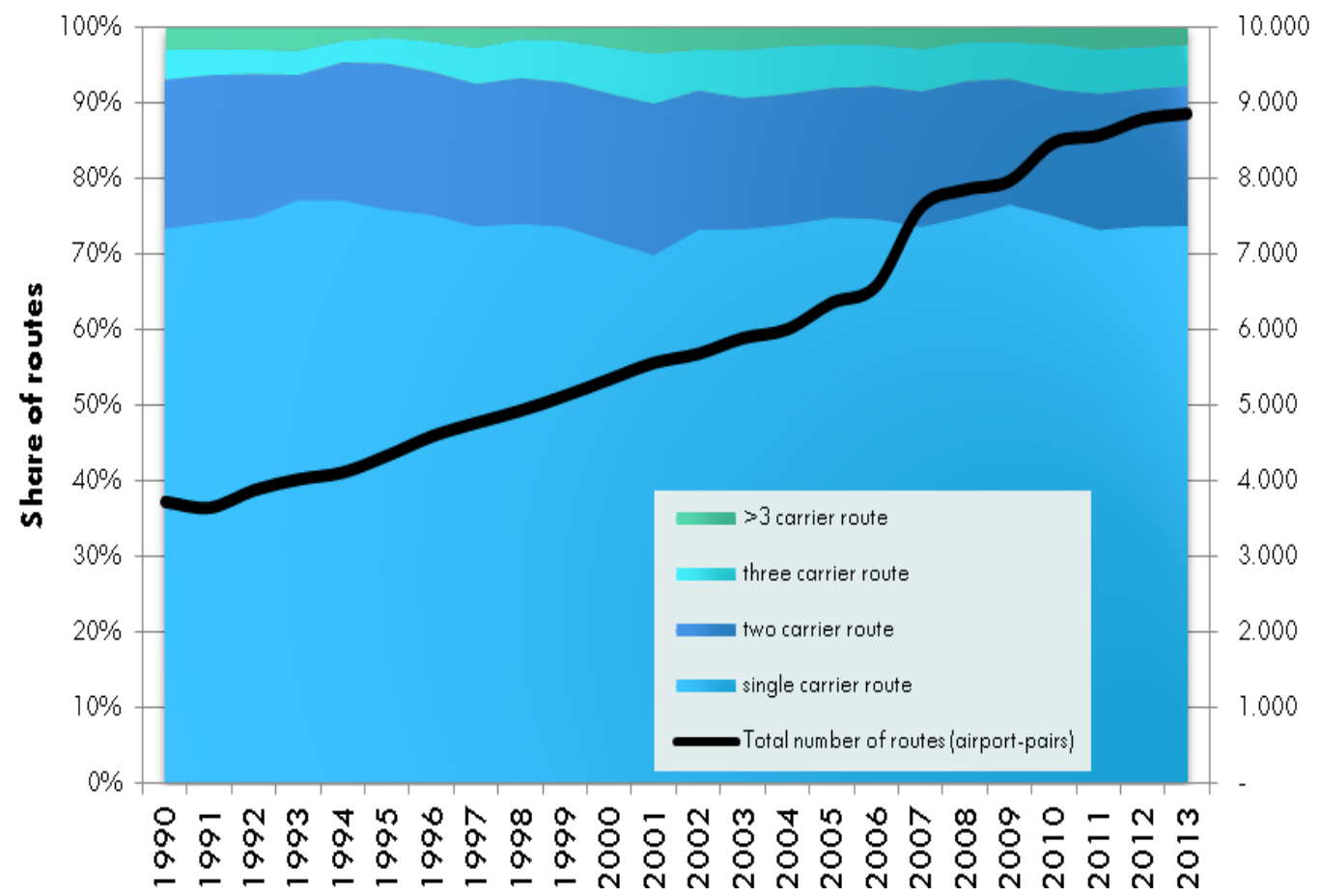

Source: OAG; analysis by authors

\section{Use of freedoms}

The extent to which carriers have actually made use of the extended 'Freedoms of the Air', in particular with respect to the use of 7th-9th freedom rights (Annex 1) is an important indication of the impact of the liberalisation and creation of a common EU aviation market is.

For a selection of EU flag carriers and low-cost carriers we have categorized their intra-EU operations according to type of freedom used. As already noted in the Creation of the Internal Market section, we must conclude that the full-service carriers mainly used the freedoms of the liberalized market to increase 3rd/4th freedom operations between their country of origin and other EU countries (Figure 8) (and combined them into 6th freedom in order to carry transfer traffic). The far majority of their operations consists of domestic and 3rd/4th freedom operations. Exceptions were certainly there: e.g. Lufthansa operated for some time a mini-hub at Milan Malpensa after the de-hubbing of Malpensa by Alitalia. The business model of the flag carriers demands concentration of the network at one or a few central hubs in order to maximize network economies. Also setting up foreign hub operations is a costly and risky undertaking. Furthermore, ongoing bilateral regulation of extra-EU air services continued to pin them down on their national home bases.

8 see Note 3. 
Figure 8. Categorisation of intra-EU15+2 services by freedom of the air for selected European carriers

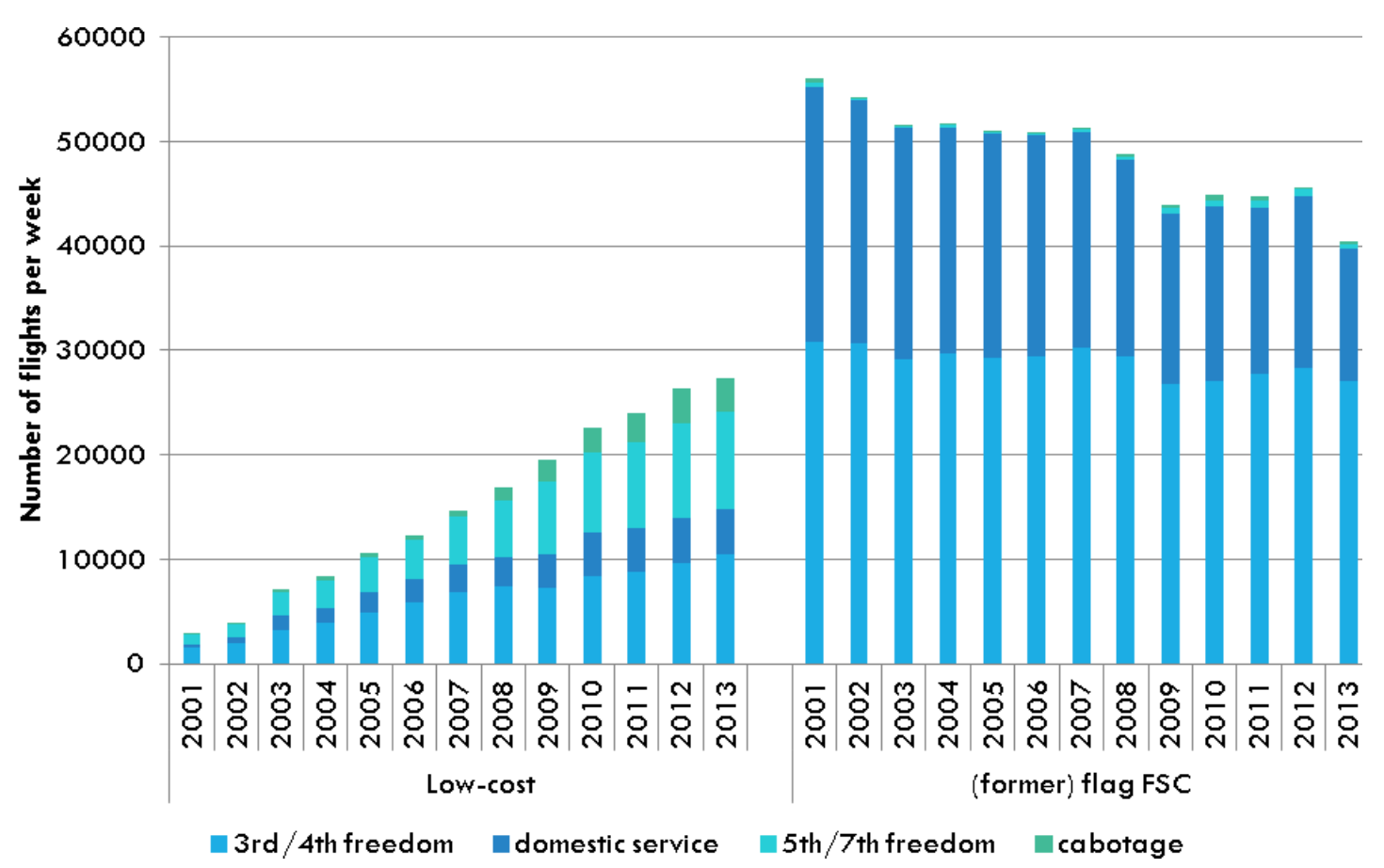

Source: OAG; analysis by authors 9

The results for the flag full service carriers contrast sharply with the operations of the low-cost carriers. Over $45 \%$ of the low-cost carrier operations in 2013 were $5^{\text {th }}-9^{\text {th }}$ freedom operations. This result is in line with the earlier findings of Dobruszkes (2009) for 2005. Their low-cost business model is fully focused on the current Common Aviation Area, avoiding complex hub-and-spoke operations. This allows for panEuropean operations more easily than the flag full-service carriers, which have to combine their European operations with their long-haul network at their hubs under the bilateral air service regime (see above).

Selection of EU carriers: (former) flag full-service carriers except SAS and the low-cost carriers as defined in this paper (see Annex 2) 


\section{The emergence of low-cost carriers in Europe}

Which airlines belong to the low-cost carrier category?

An important impact of the open aviation market in Europe is the emergence of the low cost and low fare airline (low-cost carrier) business model.

However, the low-cost carrier model as such does not exist. A wide range of business models can be observed that more or less correspond with the low-cost carrier characteristics. Budd et al. (2014) distinguish 1. diversified charter operators such as airberlin, Jet2 and Transavia, 2. Southwest copycats such as easyJet, Norwegian, Wizz Air and Ryanair and 3. Full-service carrier subsidiaries such as Vueling, germanwings.

The lists of airlines classified as low-cost carriers in the literature strongly depend on the selection criteria applied in the various analyses. For example, Budd et al. (2014) require the application of eight out a larger set of cost minimisation strategies for an airline to be qualified as a low-cost carrier, resulting in a set of 10 carriers still operating in the market of 2012. These criteria are partly comparable with the selection criteria used by Klophaus et al. (2012). But even then the resulting set of 20 selected airlines is remarkably different from the one Budd et al. (2014) selected. Dobruszkes (2013) also provides a substantially different set of 16 low-cost carriers in 2012. He selects airlines, which offer fares of around EUR 0.10 per seatkilometer and/or half the price offered by the incumbent carriers.

Not only the selection criteria play a role in the resulting set of low-cost carriers. The geographical dimension is also important. It is obvious that the EU12 shows a different set of low-cost carriers than the EU28 or the European Economic Area (EU12+3, namely, Norway, Iceland and Lichtenstein, also referred to as EEA). Budd et al. select airlines within the European Economic Area, whereas Dobruszkes (2013) makes selections from the whole current Common Aviation Area.

Thirdly, the time dimension contributes to the differentiation in low-cost carrier selection. Budd et al. (2014) report 43 low-cost carrier airlines in the European Economic Area that entered the market whereas 33 of them left the market between 1992 and 2012. So also the timeframe or the year of the analysis matters.

The low-cost carrier selection we use in this analysis is comparable with the selection of Budd et al. (2014). However we mainly focus on 'Southwest copy cats'. This resulting selection is summarised in Annex 2 that not only shows the market entry and exit (if applicable) in the period 1990-2013 but also the performance of each carrier in the years of operation for airlines in the EU15+2. Annex 3 shows the different low-cost carrier selections found in the literature. 
Figure 9. Categorisation of intra-EU15+2 services by freedom of the air for selected European carriers

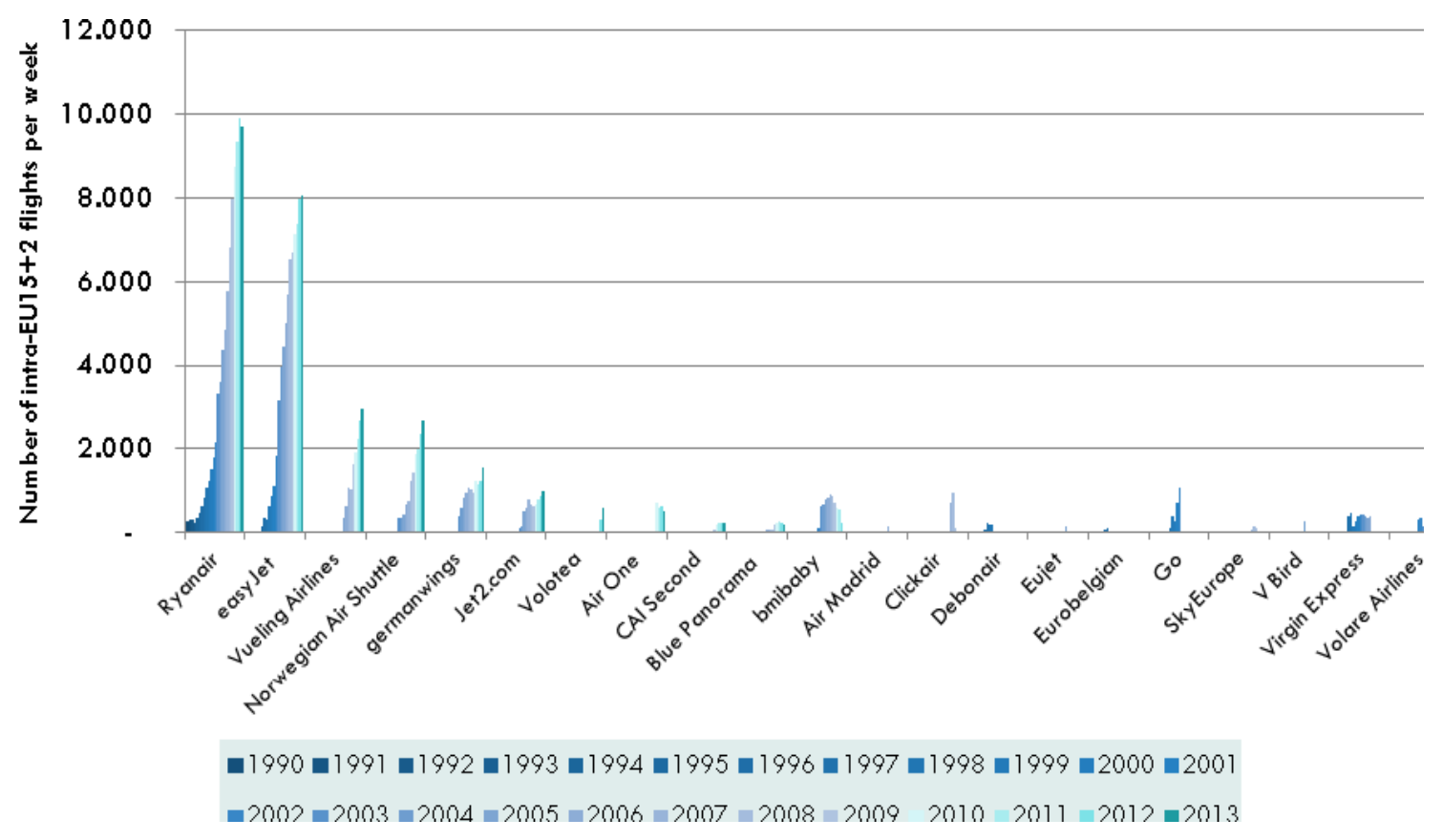

Source: OAG; analysis by authors ${ }^{10}$

Figure 9 shows the rapidly growing market size of the individual low-cost carriers included in our analysis. This clearly illustrates the dominant role of Ryanair and easyJet, followed by the second tier lowcost carriers Vueling Airlines, Norwegian Air Shuttle and Wizz Air. Note that the last one is missing here due to the consequence of only considering airlines operating services within the EU15+2 areas. Further note that the continuous and rapid growth of Ryanair is interrupted in 2013.

The low-cost carrier figures in this paper are based on the selection in Annex 2, unless indicated otherwise.

\section{Market share of low-cost carriers in the intra-European market}

The low-cost carriers rapidly made substantial inroads in the intra-EU market after the liberalisation (Figure 4), partly by generating new demand on unique routes partly by cannibalising demand of fullservice carriers in direct competition on the same routes and partly also indirectly on parallel or semi parallel routes. The low-cost market share in Europe grew in the period 2001-2013 from 3\% to 27\% ${ }^{11}$. The difference in airfares between full-service carriers and low-cost carriers reflected in the structurally lower unit costs strongly contributed to this growth in market share by generating new low fare demand.

10 Selection of EU carriers: (former) flag full-service carriers except SAS and the low-cost carriers as defined in this paper (see Annex 2)

11 Note that the low-cost share only includes the share of low-cost carriers in intra-EU15+2 flights by EU15+2 carriers. Within EU-28, this share is likely to be higher. 
Figure10. Unit cost differentials for selected European FSCs and LCCs in 2012

Unit costs (cost per available seat kilometre, EUR cent) and average sector length for selected European legacy and low-cost carriers: 2012*

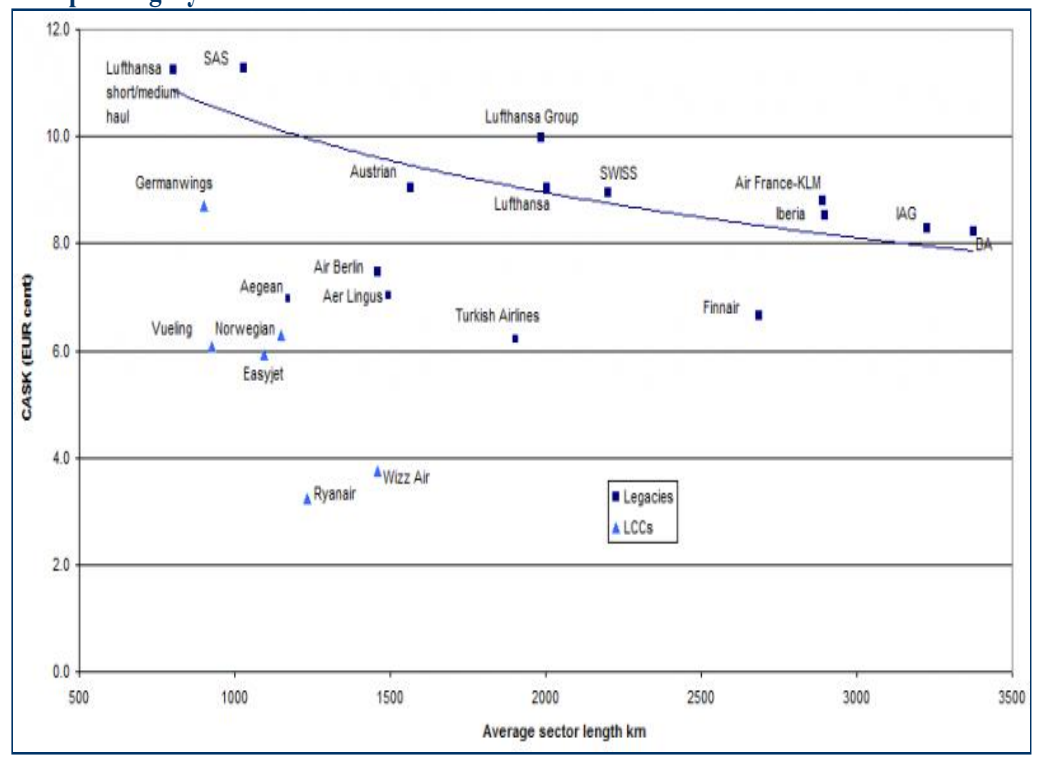

*Financial year ends as follows: Germanwings Dec-11, Aegean Airlines, Air Berlin, Turkish Airlines, Lufthansa, Aer Lingus, IAG, Iberia, BA, Air France-KLM, Finnair, Norwegian, Vueling Dec-2012; SAS Oct-2012; easyJet Sep-2012; Wizz Air, Ryanair Mar-2012.

Source: CAPA analysis of company accounts and traffic data

Figure 11. Annual growth of the number of low-cost carrier intra-EU15+2 flights 1990-2013, compared to previous year

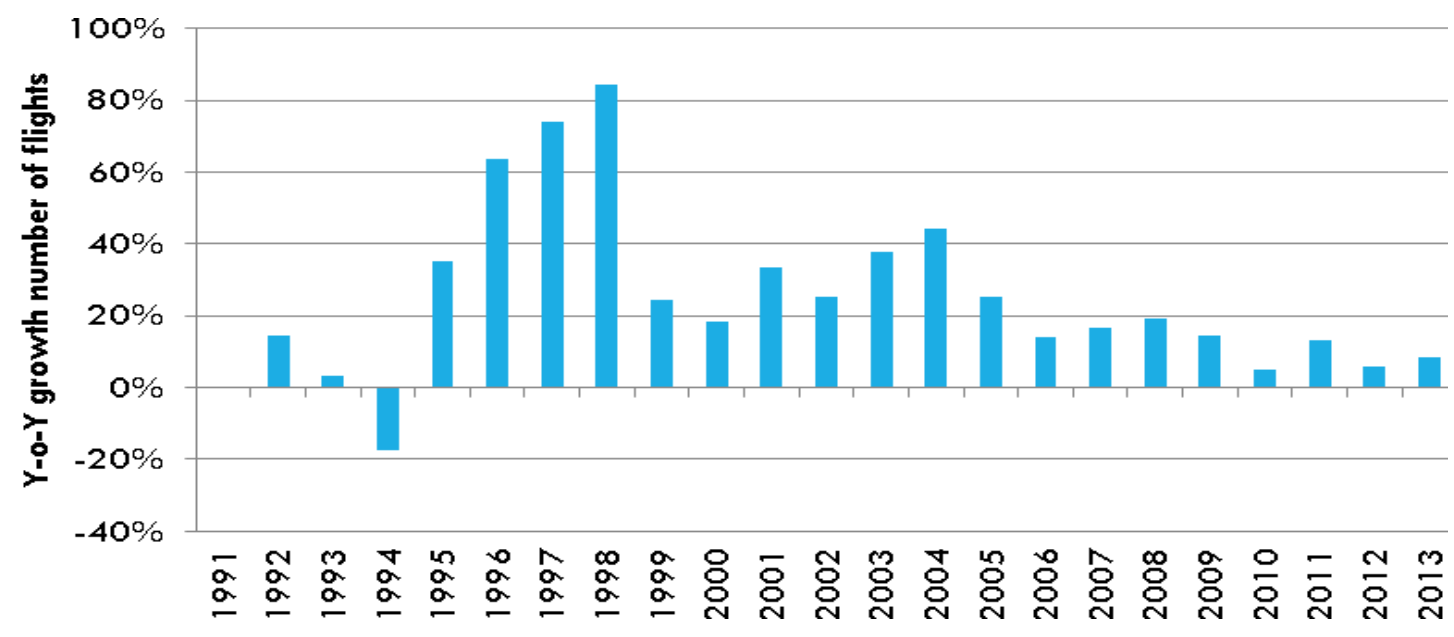

Source: OAG; analysis by authors 


\section{Saturation of the low-cost market?}

There are symptoms of saturation involved in certain markets or in some versions of the low-cost business model. De Wit and Zuidberg $(2012$; 2014) observe that the so-called route density problem is becoming a growing obstacle for ultra low-cost carriers such as Ryanair that primarily operate on low density routes between secondary airports. Testing the viability of new low-density routes results in an increasing route churn and as a consequence the focus is shifting to more primary airports looking for new higher density, less seasonal and higher yield routes. This may result in more direct competition between the two biggest European low-cost carriers, easyJet and Ryanair as well as more direct competition with the full-service carriers at their respective hubs. Note that this change in business model closely follows the same model change applied by Southwest in the US domestic market in 2007. Figure 11 provides further indications to sustain these saturation symptoms.

Low-cost carriers have returned to normal organic growth in certain EU countries. These symptoms of possible saturation are reflected in the large UK-continental Europe market (Figure 12). The substantial growth in market share of low-cost carriers was abruptly disrupted in 2008. Leigh (2014) concludes that a new plateau has been reached. The high growth period stimulated by cheap fares seems to take about 6-7 years before organic growth takes over (if any), driven by the state of the economy and disposable wealth as growth of all incumbents shows. Also other countries in Figure 12 show the first symptoms of stagnation or even abrupt decline. However, it is not clear whether in the aftermath the financial crisis also plays a role in the demand for low-cost carriers in countries such as Italy, Spain and Ireland.

All in all, it is not unlikely that a further increase in market share of low-cost carriers will be more the result of an increasing cannibalisation of the full-service carrier market share at the hubs instead of a more rapidly growing demand generated on new secondary routes.

Figure 12. Number of low-cost flights) (A) and share of low-cost in total number of intra-EU15+2 flights (B) for a selection of originating countries, 1990-2013

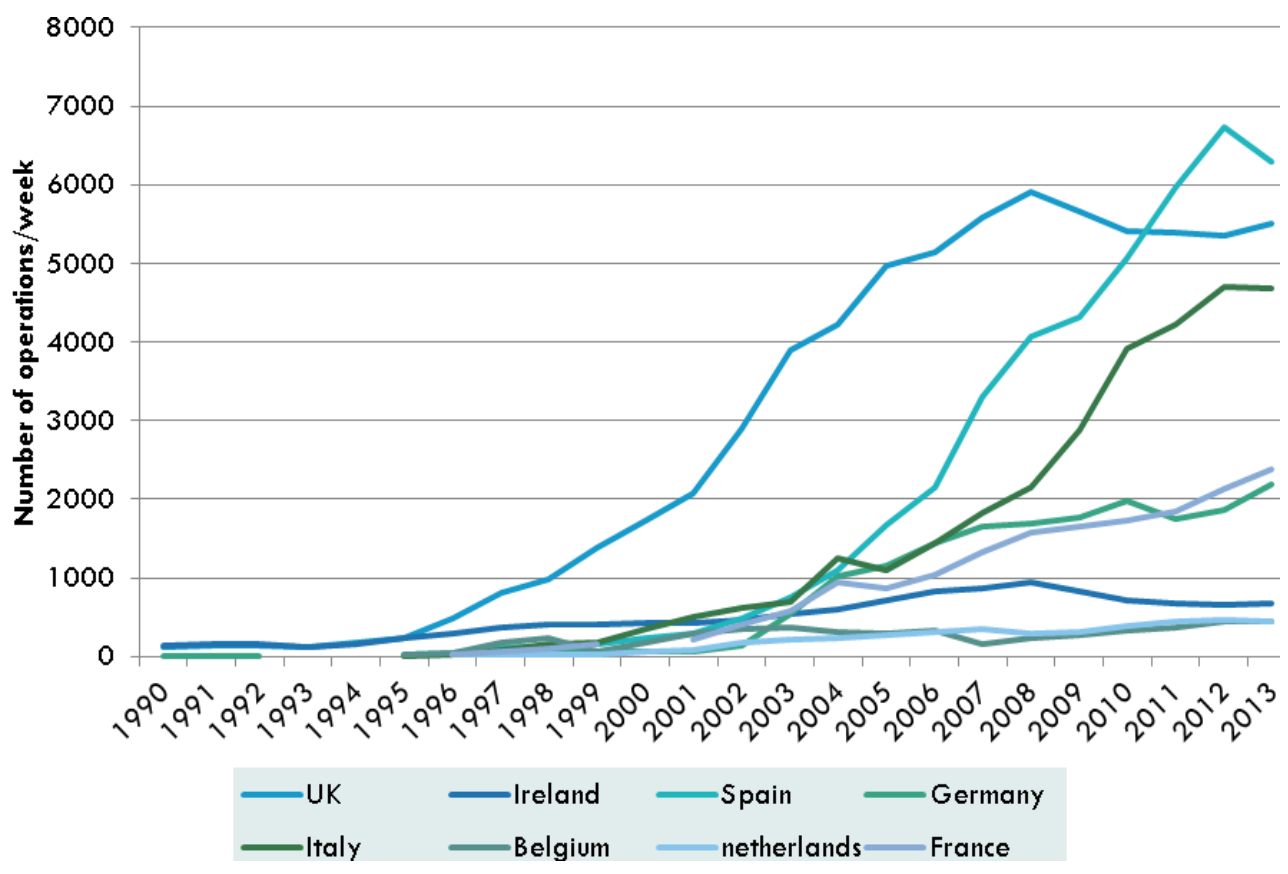




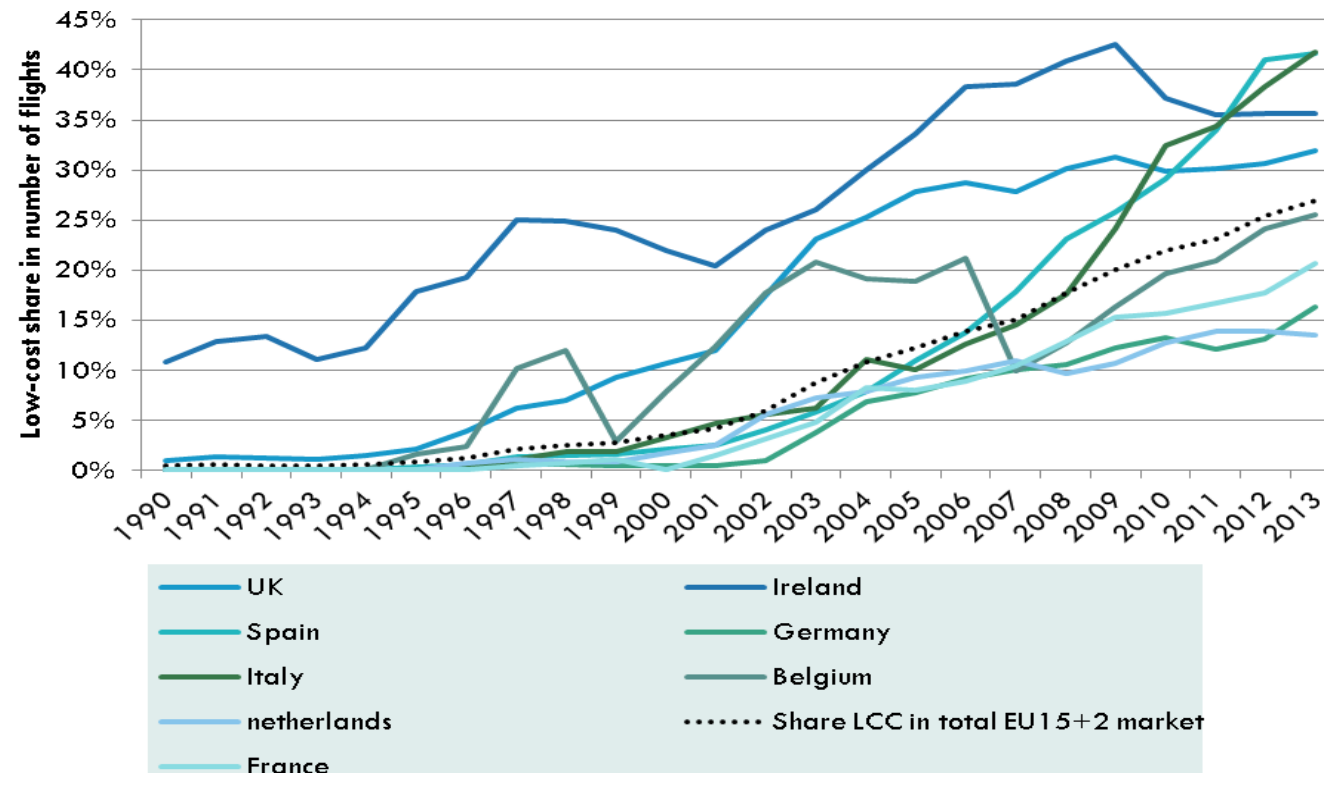

Source: OAG; analysis by authors

\section{Exposure to low-cost competition}

The next question is how these low-cost carriers compete with each other in their (until recently) rapidly growing networks (see total number of routes in Figure 13 from a few hundreds in 2000 to about 4250 in 2013). Surprisingly, Figure 13 reveals that the majority of the routes in these high growth networks (ca. 70\%) are lacking any direct head to head competition after the low-cost carrier business model started to take-off in the European market in in the early 2000s. Also in 2013 the share of multi-carrier low-cost carrier routes remains limited to $34 \%$ versus $33 \%$ in 2002, whereas in the intermediate period this share even decreased to $25 \%{ }^{12}$

Figure 13. Total number of low-cost routes (intra-EU15+2) and share of route class by number of operators, 1990-2013

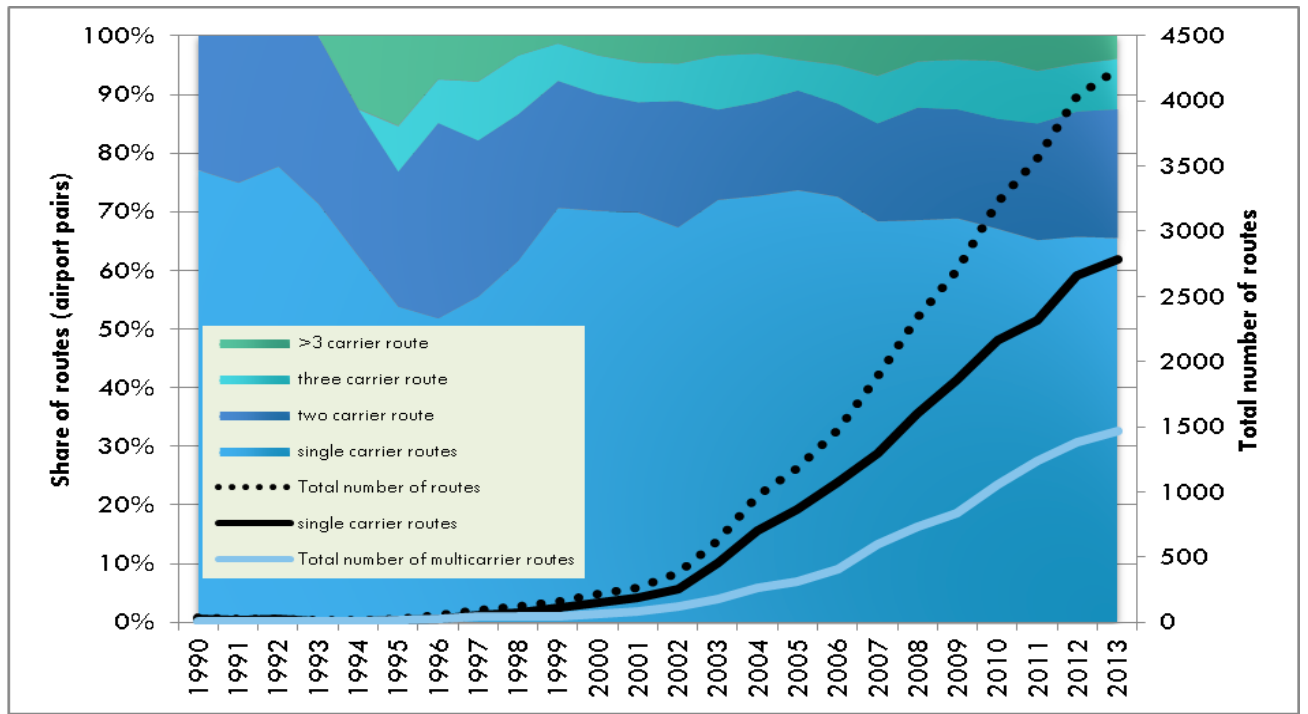

Source: OAG; analysis by authors

12 It should be noted however that this relatively stable percentage concerns a rapidly growing absolute number of routes with head to head competition to almost 1500 in 2013.

G. Burghouwt, et al. — Discussion Paper 2015-04 — (C) OECD/ITF 2015 
Especially in the first part of the 2000s the number of low-cost carrier new entrants in the market was substantial (Annex 2). However, the effective number of carriers hardly changed after 2000 (Figure 14). The main players in the market, primarily the first tier of Ryanair and easyJet, were already able to acquire a dominant role in the low-cost market. Even later market entrance of the second tier low-cost carriers, such as Norwegian, Vueling (and Wizz Air) hardly affected the number of effective carriers. The impact of other new entrants in the third tier was too small to have any impact in the market anymore (see also Figure 14).

Figure 14. Number of low-cost carriers and number of effective low-cost carriers (1/hhi) operating flights within EU15+2, 1990-2013

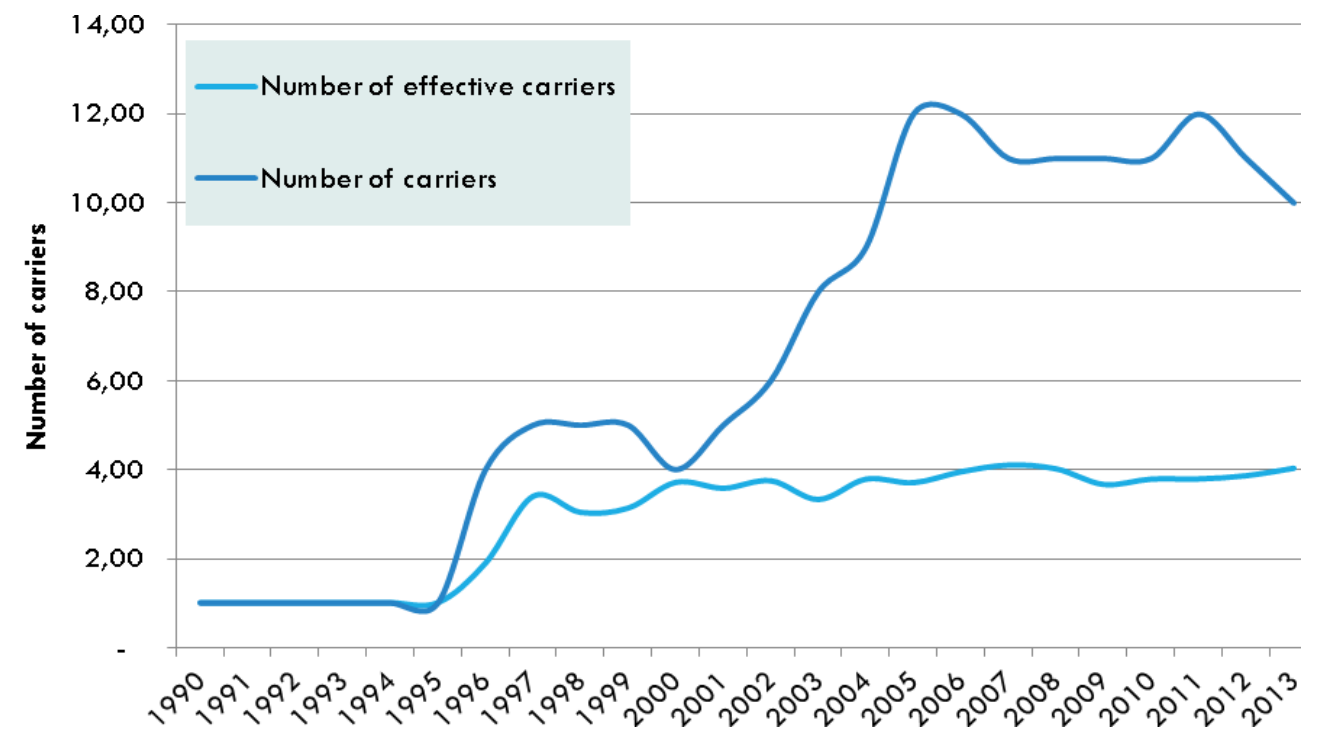

Source: OAG; analysis by authors

\section{Direct and indirect competition of low-costs and full-service carriers}

Since Dresner et al (1996) indicated that the competitive impact of low-cost carriers on fares of incumbent carriers is greater than on directly competed routes due to spillover effects - the so-called 'Southwest effect' - it is likely that the competitive effect of low-cost carriers on fares of the incumbents is not restricted to the routes where low-cost carriers and full-service carriers directly compete directly but also on adjacent routes. Adjacent competition may concern semi-parallel routes such as Amsterdam- Rome Fiumicino (KLM) versus Amsterdam- Rome Ciampino (easyJet), and full parallel routes such as Eindhoven Rome-Ciampino (Ryanair) versus Amsterdam Rome Fiumicino (KLM).

Morrison (2001) even found substantial fare reduction effects of incumbents on routes of which only the origin airport and/or the destination airport is served by the low-cost carrier but not the route itself, the so-called potential competition. The presence of low-cost carriers in the European market have a fare reduction effect on full-service carriers, which seems to be the strongest in case of direct competition but also in case of adjacent competition and even when potential competition is at issue. The various low-cost carrier sub models manifest themselves differently in these three categories of competition. For example the easyJet model will cause fare reduction effects in all three categories of direct, adjacent and potential competition. The Ryanair and Wizz Air model will much more indirectly affect full-service fares on parallel routes as long as they focus on routes between secondary airports. The business model change announced by Ryanair in 2014 implies more competition with an increasing number of full-service carriers if their hubs started to be served by Ryanair as well. This does not only concern direct competition on fullservice carrier feeder routes but also adjacent competition on semi-parallel routes from the hub and potential competition on European routes to and from the hub involved. First examples of this model 
change are Athens, Rome, Brussels, Madrid, Lisbon and new candidates of smaller hub airports with weaker full-service carriers will probably follow.

Figure 15. Percentage of routes shared by low-cost carriers and (former) flag full-service carriers

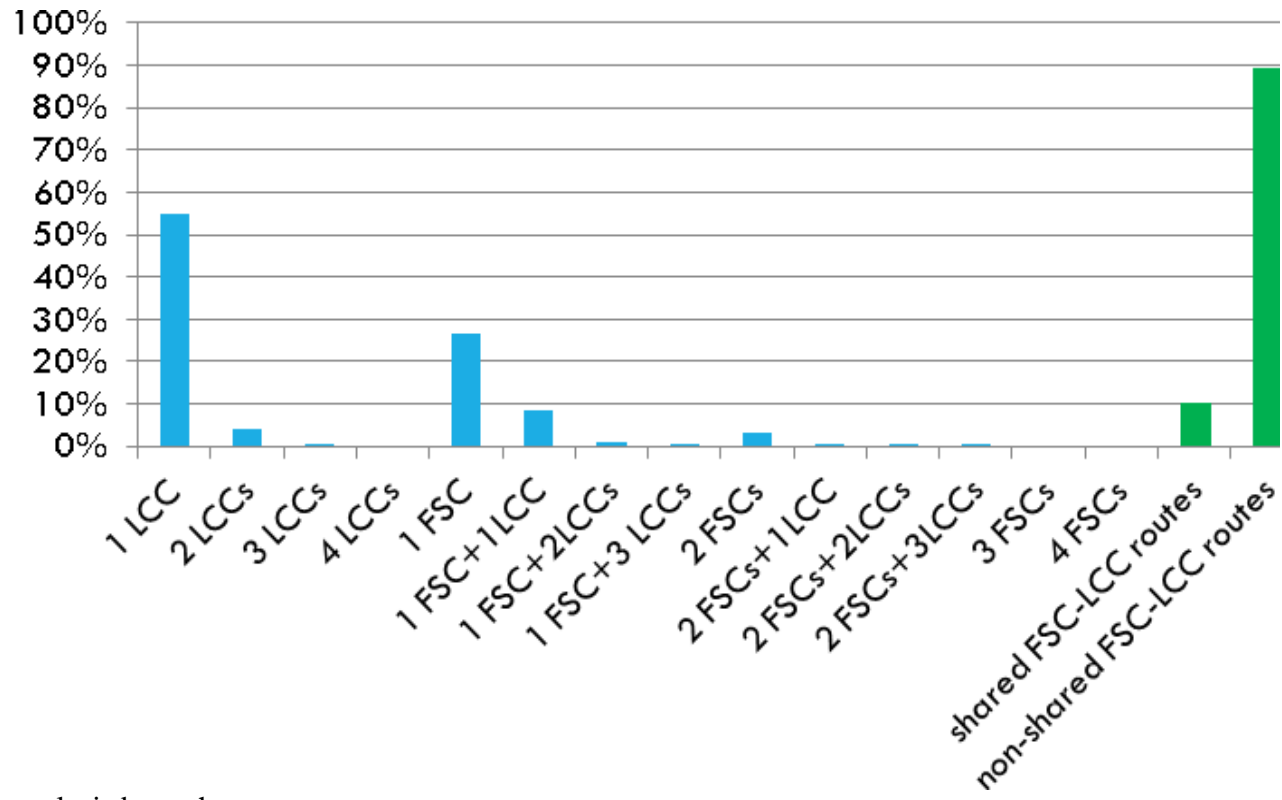

Source: OAG; analysis by authors

The development of direct competition between low-cost carriers and full-service carriers can be derived from Figure 15 that reflects the shares of routes commonly served by low-cost and full-service carriers in Europe between in 2013. These relative shares hardly changed in the previous years. Hence, direct competition between the carriers of the two business models remains limited to ca. $10 \%$ of the routes. However, this percentage may increase due to the changing route strategy of the largest low-cost carrier, Ryanair, when it starts to focus more on primary airports rather than secondary airports. Until now, the direct, head to head competition between full-service and low-cost carriers is limited. The more remarkable is the absence of direct head to head competition at the majority of low-cost carrier routes. One should however bear in mind that the route density is not reflected in Figure 14. This will probably imply that the number of low-cost single carrier routes often concerns low density and low frequency routes between secondary airports.

Effects of the second category i.e. potential low-cost carrier competition manifest themselves in most of the full-service carrier European networks due to the presence of low-cost carriers at their hubs. Exemptions are probably only BA at London Heathrow and Lufthansa at Frankfurt.

For a full picture of the impact of low-cost carrier competition on full-service carrier fares and yield the third category, i.e. adjacent competition should also be taken into account. However this requires an extensive analysis of individual airline networks, which goes far beyond the scope of this paper. Such an approach, although relevant with regard to low-cost versus full-service carrier competition, also implies a wider concept of the relevant market than applied by the European Commission in its point of origin - point of destination approach. 
The fare and yield development of full-service carriers have not only been affected by the competition with low-cost carriers. Also the hub-and-spoke systems of the full-service carriers themselves started to compete increasingly with each other as the number of spoke routes in Europe rapidly increased at the various hubs as well as the frequencies on these spoke routes to serve the increased number of enable more daily connection waves at these hubs. Intra-European routes from the hubs encountered more and more competition from indirect European routes via competing hubs in Europe, especially in the non-business segment.

In sum, after the liberalisation of the internal air transport market the effects of new competition have resulted in a very substantial real yield decrease in the European market for AEA airlines in Figure 16: from $21 \notin$ in 1990 to $9 \not$ in 2013. Whether this decrease is fully to the benefit of the consumer remains to be seen. To enable an answer requires an analysis of many other (social) costs and benefits, which is beyond the scope of this paper.

Figure 16. Total Europe (incl. domestic) passenger yield, US $\$ /$ RPK

Source: AEA

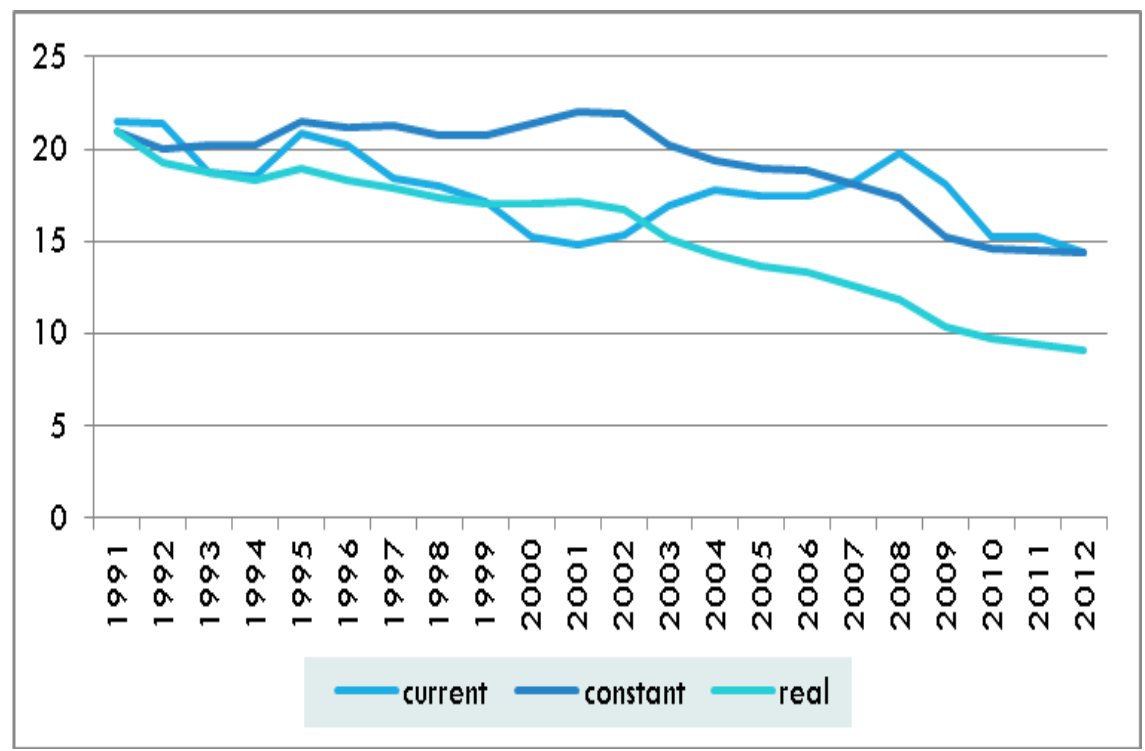

\section{Impact on the EU airport hierarchy}

The rise of the low-cost carrier has not only impacted output, competition levels and yields in the EU aviation market, but has also drastically altered the balance in seat capacity supply among the European airport population. In an analysis of seat capacity supply over the period 1990-2009, Sanchez et al. (2014) find that the growth of low-cost carriers has fostered the spatial deconcentration of intra-EU traffic, as part of the low-cost carriers allocate part of their seat capacity at secondary airports so as to avoid the high airport charges and cost associated with congestion. Thus, while low-cost carrier networks in itself are still relatively concentrated because of the radial organization around a number of home bases, overall these carriers have resulted in a more equal distribution of seat capacity over the EU airports, with more opportunities for traffic growth of small airports.

However, looking at the potential signs of saturation of the low-cost market and- in response to thisaltering network strategies of low-cost carriers such as Ryanair, it is not unlikely that the deconcentration impact will be less strong in the future. 


\section{Development of full service network carriers in the liberalised market}

The rise and consolidation of EU hubs

After the deregulation of the US domestic aviation market, the majors adopted temporally and spatially concentrated hub-and-spoke networks to benefit from cost- and demand-side economies as well as to deter entry. The question is if the liberalisation and creation of the common EU aviation market provoked a similar network reaction from the EU State's 'flag' carriers.

\section{The rise}

As explained in the Growth of the Flag Carrier and Hub-Systems section, the EU liberalisation departed from a different 'aeropolitical' point than US deregulation in the sense that international air services from the EU countries were pinned down on the national airports functioning as their principal hubs because of restrictions imposed on the operation of international air services by bilateral air service agreements, focusing on the carriage of third and fourth Freedom traffic (see also the Progressing Liberalisation section). This resulted in radial, spatially concentrated networks operated by the European 'flag' carriers long before liberalisation took off. Thus, these networks were not hub-and-spoke networks in a strict sense but the result of the prevailing aeropolitical regime. In contrast, the networks of the US majors were spatially deconcentrated, crisscross networks before deregulation in 1978. Hence, it will be no surprise that spatial concentration as part of the formation of hub-and-spoke networks by EU carriers did not take place to any large extent (Burghouwt 2007), apart from intensification of these radial networks in terms of frequencies and number of routes.

However, EU liberalisation did trigger the rise of hubs in the second half of the 1990s through the temporal concentration of flights at the hubs by means of wave-system structures (Burghouwt and De Wit 2005; Burghouwt 2007). National carriers that already operated rudimentary wave-systems in the early 1990s at some of their home bases intensified and optimized their wave-structures, which entailed amongst other things a tighter schedule coordination of arriving and departing flights and an increase in the number of connection waves. Examples of intensified hubbing during the 1990s are KLM at Amsterdam, Lufthansa at Frankfurt, Sabena at Brussels, Swissair at Zurich and SAS at Copenhagen. In addition, a number of national carriers set up wave-systems at their national airports almost from scratch. Air France implemented hub-operations with wave-systems at both Paris CDG and Lyon. Iberia did the same at Madrid and Barcelona. Lufthansa developed a secondary hub at Munich, Alitalia at Rome Fiumicino and Milan Malpensa and British Airways at London Gatwick.

As a result, a considerable number of airline hubs was scattered over the EU at the end of the 1990s (Figure17). Most of them were hinterland hubs, connecting continental European traffic with intercontinental destinations. Some of them merely had a regional function, such as Lyon (Air France), Basle (Crossair) and Clermont-Ferrand (Régional), while others used the hub concept to ease seasonality patterns in demand (airberlin at Palma de Mallorca). The build-up of hubs generated substantial growth in both connectivity to, from and via the hub as Burghouwt (2007) demonstrated. 
Figure 17. The rise and consolidation of European hubs (EU15+2), 1990-2010
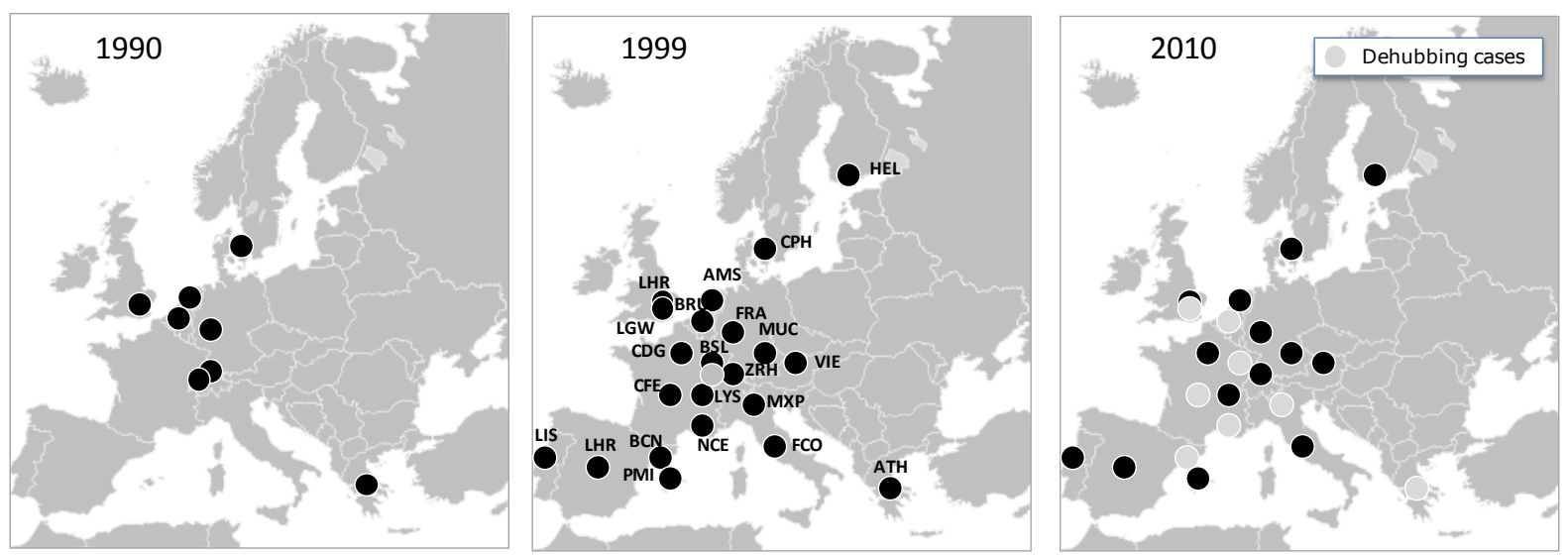

Source: adapted from Burghouwt (2007) and author's analysis. Note: hubs are airports that host hub-carrier operating a wavesystem at the airport or a large airport with over $30 \%$ transfer traffic.

\section{Consolidation}

Since the start of the millennium, the hub build-up has come to an end and has been replaced by a phase of rationalization and de-hubbing. First, this is the result of the bankruptcy of the carriers Sabena (Brussels), Swissair (Zurich), Air Littoral (Nice) and Spanair (Barcelona), which resulted in the demise of the respective hubs Brussels and Zurich as well. Only Zurich was able to recover its hub status with Crossair/Swiss continuing on the remains of bankrupt Swissair.

Secondly, (former) 'flag' full service carriers have rationalized their networks in response to increasing competition, rising fuel costs and adverse economic conditions. In addition, additional network economies could be achieved by consolidating traffic at one hub instead of spreading the hub operation over two hubs in relative proximity to each other. Major de-hubbing cases include the de-hubbing of Milan Malpensa by Alitalia (and consolidation of the network at Rome, 2008), Barcelona by Iberia (consolidation at Madrid, 2006) and London Gatwick (consolidation at Heathrow, 2000). Figure 18 summarizes the hub connectivity developments during the past decade in terms of the number of realistic connections offered via the hub, divided by the total number of direct connections, the so-called feeder value. It clearly shows the impact of de-hubbing at Barcelona, Malpensa and Gatwick on the airport's connectivity performance, as well as the rationalization of hub operations at Copenhagen and Vienna.

The impact of de-hubbing on the respective airport is long lasting. Redondi et al. (2012) studied over 50 de-hubbing cases worldwide and found that de-hubbed airports do not recover their original traffic volumes within a 5-year time period. Furthermore, airports that lose their hub status generally do not regain that status, at least not in the short to medium term. 
Figure 18. Feeder value of major EU hubs in 2004 and 2014

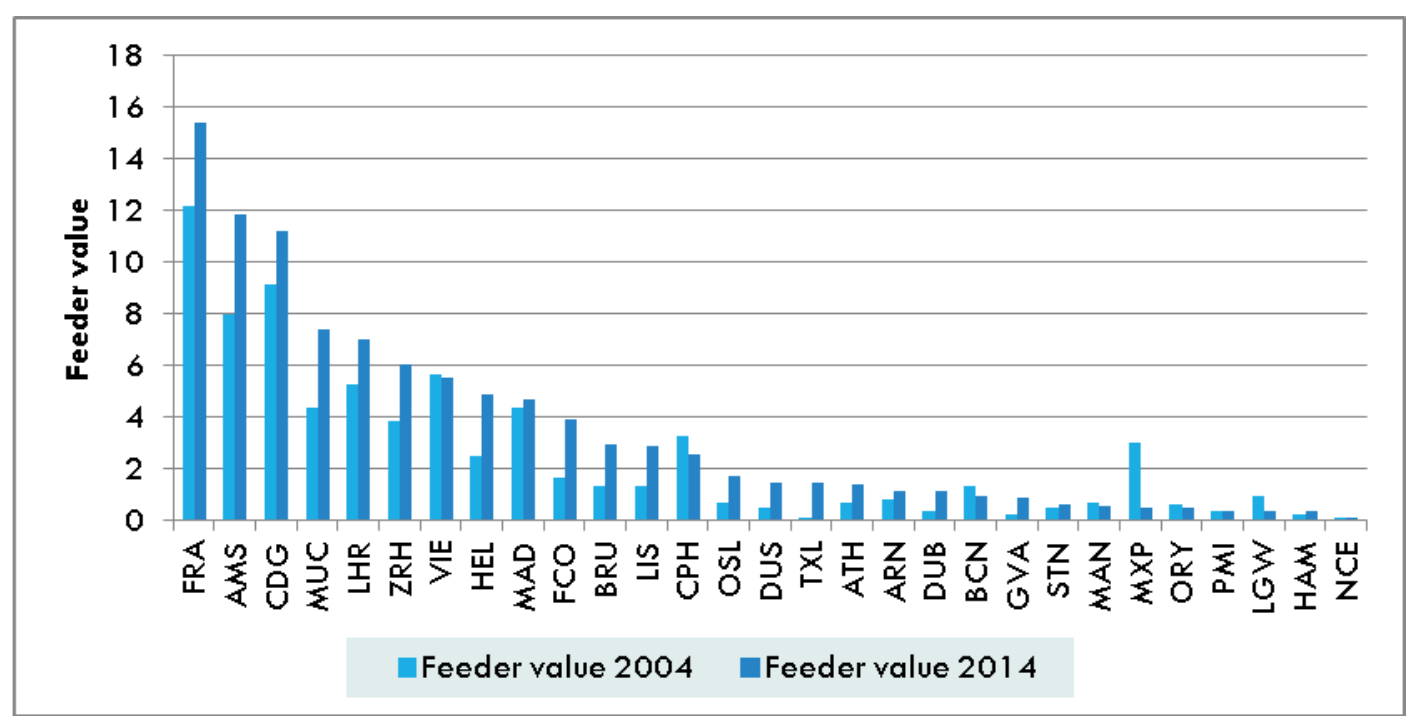

Source: ACI Europe (2014); SEO analysis; OAG. Note: number of hub connections with a transfer at the hub has been measured with the Netscan connectivity model. See Burghouwt and Redondi (2014)

\section{EU flag carriers under pressure}

The business model of the (former) 'flag' full service carriers is under increasing pressure. Since 2000, the share of this carrier segment in the total supply of intra-EU flights has been decreasing (see Figure 4). Full-service carriers experience more competition on the route level and the share and number of 'monopolized' airport-pairs is decreasing (Figure 19), while adjacent and potential competition from lowcost carriers is on the rise. Furthermore, financial results of the EU 'flag' carriers have been weak or negative- as reflected in IATA's Vision 2050). 
Figure 19. Number of routes (airport-pairs) operated by (former) flag full-service carriers and share of type of routes by number of carriers, 1990-2013

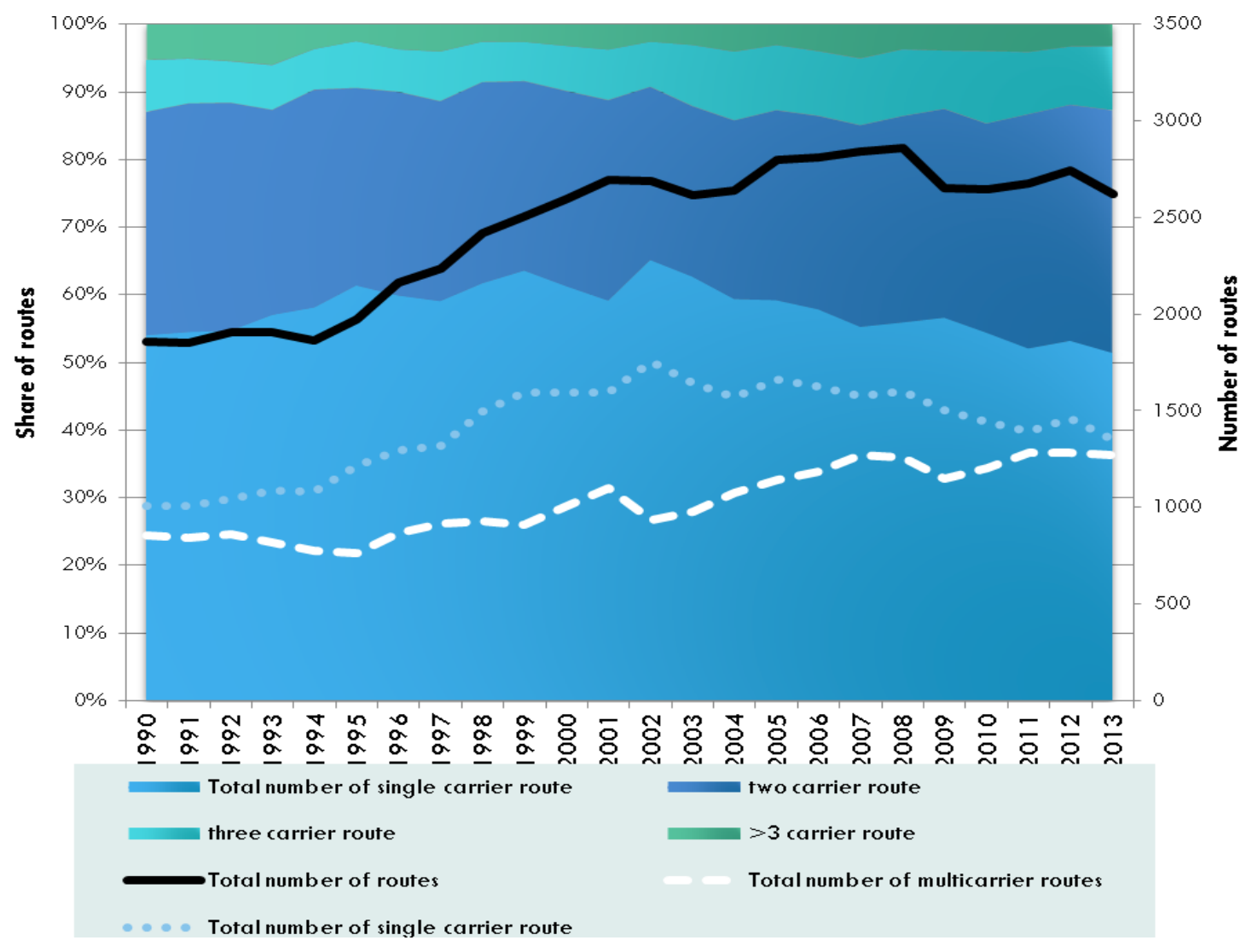

Source: OAG; analysis by authors

The number and size of the (former) flag full service carriers in Europe was primarily determined by the political forces of having a flag carrier in each member state when market forces started to have their impact on the liberalized market. These market forces will continue to work into the direction of a less fragmented European market through on-going consolidation. Expensive hub-and-spoke systems are increasingly exposed to low cost carrier competition on short haul routes. A revival of long haul, low cost operations from and to Europe is also likely to increase, as well as the growth in competition of the Gulf carriers operating a cheaper long haul network at their hourglass hubs in an unlevel playing field.

The intensifying competition will have more and more impact on European (former flag) full service carriers, which have to look not only for further cost-cutting opportunities but even more have to improve their hub connectivity to keep their networks as attractive as possible. These economic forces will continue to change the landscape of the former national carriers in Europe. Since Chapter 11 options are missing in the EU the likelihood of further market consolidation through bankruptcies, take-overs and mergers will remain substantial.

\section{Consolidation of the European airline industry: mergers, take-overs, alliances and the impact on competition}

In general terms causes of consolidation are usually mergers and take-overs, bankruptcies and horizontal cooperation. The main driver in network industries are the network economies such as density economies in existing networks and scope economies in extended networks. The coupling of continental hub \& spoke systems of alliance partners in various continents clearly is an important alliance advantage. 
When after the liberalisation competition between hub and spoke systems of the new full-service carriers increased, and the often indirect competition with the new low-cost carriers intensified, network size became an important competitive tool for full-service carriers. This was primarily effectuated by code sharing agreements and later by ever growing alliances (see for the regulation of competition section).

Alliances refer to any kind of horizontal co-operation between airlines (excluding mergers), which may widely vary in scope, and strength. The reasons for entering in cross border alliances instead of mergers partly have a legal background, i.e. trying to circumvent problems related to the nationality clause in the bilateral air service agreements between the states involved (see further below), and partly an economic reason, i.e. the benefits of an increasingly global network can be realized through an increasing number of alliance members worldwide. The depth of alliances can widely differ, running from simple interlining agreements, via code sharing agreements to merger-like metal neutral joint ventures for which competitive issues such as prices, schedules, capacity, facilities are coordinated, costs revenues and/or profits are shared and a minority interest is acquired in allied partners. In the meantime diversification within alliances increases. Subsets of far reaching joint ventures manifest themselves such as the transatlantic joint venture between Delta, (including Northwest), Air France, KLM, Alitalia and CSA, as well as the oneWorld joint venture between American Airlines, British Airways, Finnair, Iberia and Royal Jordanian. Also low-cost carriers are increasingly considered as potential alliance members. Skyteam and STAR each discuss the possibility of a platform for membership with selected low-cost carriers. In the meantime the bilateral cooperation between individual alliance members and low-cost carriers from other continents also increase.

Since domestic carriers in the US domestic market were not hampered by ownership and control clauses in bilateral air service agreements with other countries, mergers and take-overs have been dominant in the consolidation of the US airline industry from the beginning after the deregulation. In Europe this stage of domestic consolidation in the larger EU member states had already been effectuated before liberalisation. For example BCAL, in the UK and Air Inter in France had been taken over by the national carriers in an earlier stage. (Doganis 1994). In Europe it was only in 2003, that the first cross border merger/take-over was realized between Air France and KLM. The merger model has been applied in various cross border mergers, i.e. the umbrella model as Gudmundsson (2014) characterized it. This implies a relative independence of the merging airlines under the same umbrella. This independence is maintained to safeguard the traffic rights designated to the respective merging candidates under the nationality clause included in the bilateral air service agreements with third countries outside the CAA. These third states may dispute the nationality clause in the bilateral air service agreements, if the ownership changes due to the merger. It should be emphasized however that the more the nationality clauses in bilateral air service agreements of individual member states have been replaced by a Community air carrier clause (see 0) the less is the chance of a dispute. This umbrella merger model has been adopted in more cross border takeovers, equity stakes and mergers in Europe during the first decade of this century, such as the Lufthansa Group and IAG (see Figure 21). The question is however whether this umbrella model will be further compressed into full mergers if the competitive position of FSCs in Europe continues through increased competition from inside and outside the European market. We refer for details on merger control to that section.

Another category that contributed to market consolidation concerns bankruptcies. Some of the full service carriers fully disappeared from the market, such as Malev and Slovak Airlines. However most of them have risen from their ashes as new national carrier under a new name, such as SABENA and its successor Brussels Airlines, Swiss Air replaced by Swiss international via Crossair, Balkan Air which returned as Bulgaria Air and the remains of Olympic Airways, which have been taken over by Aegean as the new national carrier. With regard to low-cost carriers the market access and network expansion of these carriers is often emphasized but Budd et al. (2014) analysed market entry and exit of low-cost carriers in the European market between 1992 and 2012 and concluded that of the 43 low-cost carriers identified in this period, 33 have left the market. Remarkably, the last two of the still existing ten carriers entered the market 
already in 2004 (Wizz Air and Vueling). It is likely that further consolidation in this market segment will continue in the future. The reasons are not primarily related to network synergies and network economies, but more to the emergence of overcapacity and demand saturation if aircraft orders are also taken into account.

One market segment that is often neglected in airline consolidation studies concerns the former holiday charters and current leisure carriers. In contrast with FSCs, horizontal as well as vertical consolidation in the value chain is an issue here. As a consequence of the third package of liberalisation the regulatory distinction between scheduled services and unscheduled services ended in 1993. Although traditional holiday charters started to be competed by LCCs this was not the most important reason for a consolidation process in the holiday charter market. Actually this consolidation was primarily a consequence of an ongoing consolidation downstream in the value chain, i.e. among the tour operators, which usually own most of these holiday charter airlines. Horizontal take-overs on the airline level are scarce, such as for example the LTU take-over by airberlin in 2007. Dominant is the consolidation in the tour operator business itself, including the charter airlines involved.

TUI Travel is a good example of the largest consolidated tourism group in Europe resulting from various mergers and take-overs and now owning several European airlines: 1. Arkefly (after the take-over of Arke Tours and HI), 2. Corsair International (after the take-over of Nouvelles Frontières), 3. Jetairfly, 4.Thomson Airways which resulted from an earlier merger between Thomsonfly (former charter Brittania Airways) and First choice Airways after the merger between TUI and First Choice Holidays in 2007, 5. TUIfly resulting from the former German airlines Hapag-Lloyd Flug and Hapag-Lloyd Express after the take-over of Hapag-Lloyd by TUI, 6. TUIfly Nordic (former Brittania Nordic and Transwede Airways)

The second largest tourism conglomerate in Europe today is Thomas Cook Group resulting from a merger with My Travel Group. Thomas Cook owns various airlines such as Condor, Thomas Cook Airlines UK (a merger between former Thomas Cook Airlines and My Travel Airways), Thomas Cook Belgium, Thomas Cook Airlines Scandinavia. Note that the former Thomas Cook Airlines emanated from JMC Air, that was the result of from the acquisitions of Flying Colours Airlines, Air World, Caledonian Airways and Peach Air by Thomas Cook in the 1990s already.

Figure 20. Total number of scheduled intra-EU15+2 operations per week of the 10 largest leisure carriers

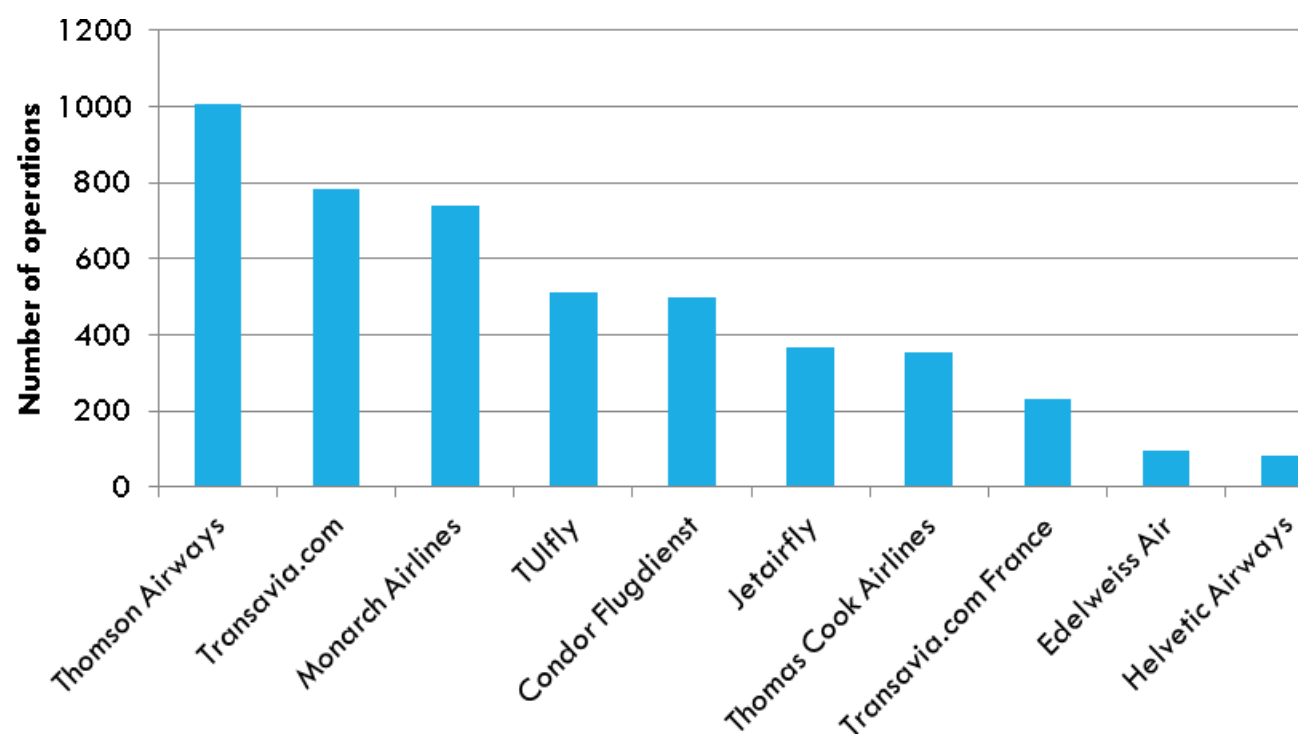

Source: OAG; analysis by authors 
Hence, not only the European FSCs substantially consolidated in the last decade but former charter airlines even more. However, the consolidation of these leisure airlines resulted from the downstream consolidation in the tourism value chain, i.e. the tour operators, that were driven by scale economies derived from integration of the various components in their value chain, including air transport. Network economies were not the basic driver such as the case is in the FSC sector. The consolidation process in the tour operator business is however an already longer lasting process starting already in the 1970s. (Kerns et al. 2009). This process accelerated in the 2000s probably also due to the increasing competition of the lowcost carriers in the Mediterranean holiday market. And as such this is a second order spin-off of liberalisation as well. In the meantime charter airlines mostly transformed into leisure airlines operating scheduled services to sun/sea/sand destinations from North-West Europe and combining the classic package tours with LCC-like seat-only products at competitive fares. For that reason it is obvious that many leisure airlines are also categorized as LCCs. (see CAPA list in Annex 3)

Figure 21. Selected mergers, take-overs and bankruptcies of legacy carriers

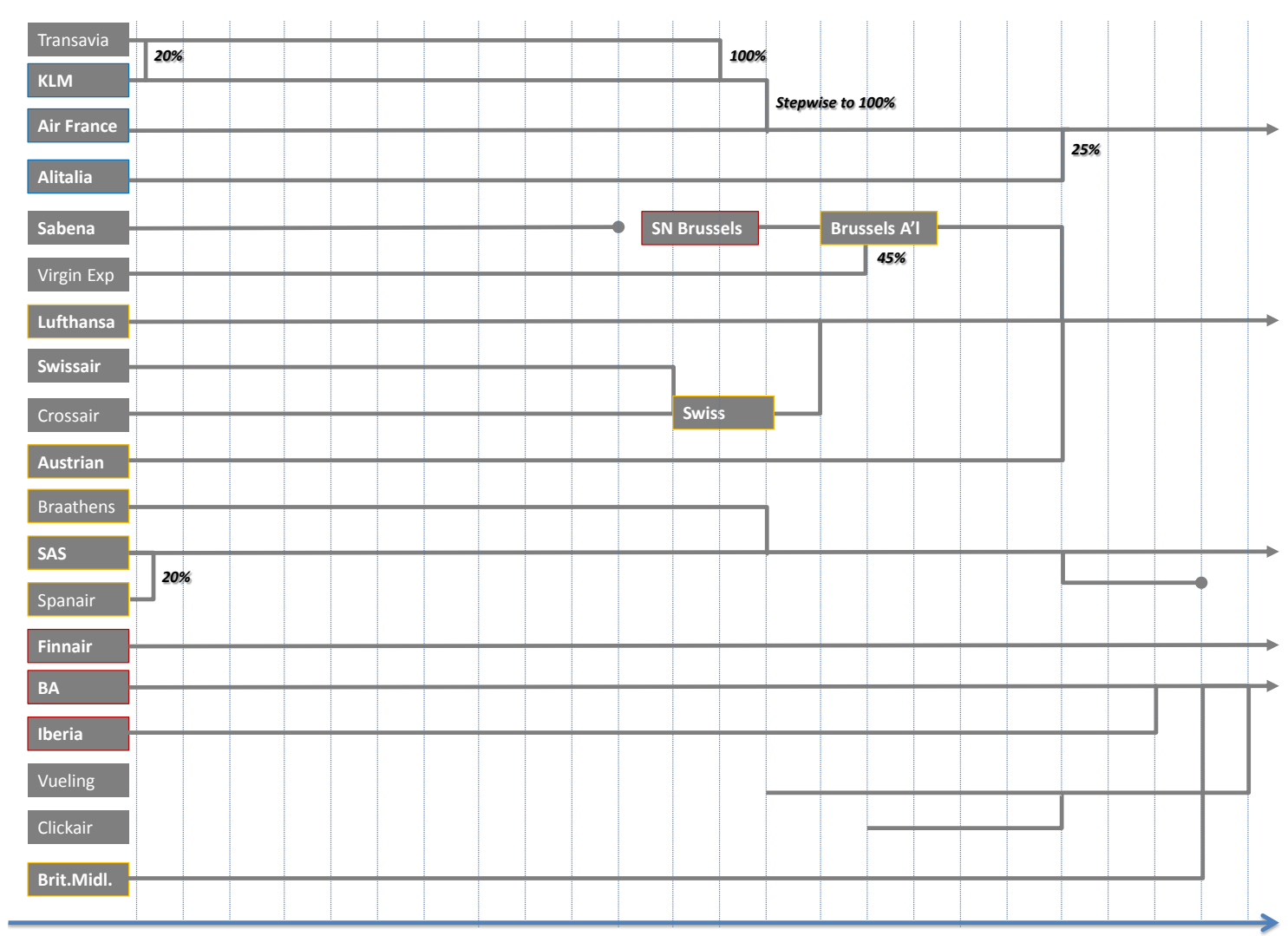

19901991199219931994199519961997199819992000200020012002200320042005200620072007200820092010201120122013

Source: analysis by authors 


\section{Airport competition and airport capacity as a competition barrier}

\section{Airport congestion in a liberalised market}

The liberalisation has resulted in a much better use of underused secondary airports thanks to the emergence of the low-cost carrier business model. It should be underlined however, that also new demand has been generated by the lower air fares offered by the new low-cost carriers and by the lower fares of the full-service carriers resulting from continuous cost reductions in a more competitive environment (See Figure 16), showing the decrease in yield development of AEA carriers). Furthermore, after the liberalisation full-service carriers intensified their hub and spoke systems and substantially increased the traffic at a number of primary airports. This process further intensified through the process of alliance building and the Open skies agreements between the US and EU member states enabling metal neutral joint ventures across the Atlantic.

All-in all, increasing airport congestion in Europe seems to stay here for the next decades and will continue to affect the functioning of the liberalized air transport market. Congestion will continue to cause substantial unaccommodated demand and hamper the contestability of individual city pair markets due to entry barriers for new competitors.

Eurocontrol (2013) estimates long term traffic volumes for 2035 based on a demand scenario with moderate economic growth. Traffic level 2035 will be 1,5 times the 2012 volume, i.e. 14,4 million flights in Europe, of which 1,9 flights cannot be accommodated.

Airport congestion will grow much faster due to the fact that the expected increase in total capacity has been scaled down substantially compared with the earlier expectations of 2008-2030. Instead of $38 \%$ reported for that period, now calculations are based on $17 \%$ increase in total capacity growth for the period 2013-2035. (Note the contrast with the rapidly expanding home bases of the Gulf carriers for example). According to Eurocontrol's definitions on congestion the number of structurally congested airports in Europe will increase from 3 to 23 (See Figure 22).

Figure 22. Airport congestion according to Eurocontrol's scenario C

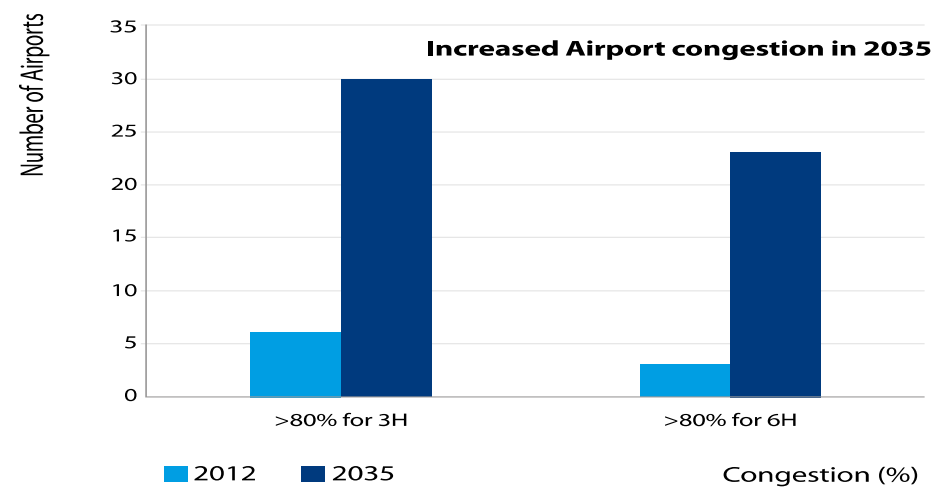

Source: Eurocontrol (2013) 
Besides a growing lack of airport capacity in Europe, also the consequence of operating at near capacity will be that the robustness of the total system is affected: primary delays will propagate through the European airline network via reactionary knock-on delays. Unusual events or disruptions in airport access may even more rapidly spread in the network.

Growing scarcity of airport capacity will therefore require new allocation mechanisms and new regulatory frameworks to not only optimally allocate the slots at individual airports but also to guarantee market access to new entrants and to remain a continuous stimulus for competition.

\section{Competition provisions as applied to the operation of airports}

As opposed to air traffic control agencies, which are regarded as State bodies, airports are considered as 'undertakings' under EU law, designed to carry out an economic activity, and, hence, subject to EU competition law. The EU Commission has never applied the EU competition rules concerning concerted behaviour to dealings as between airports, probably as they have not occurred, whereas the EU Commission holds that airport policy is a domestic affair. However, it has applied the EU rules on the abuse of a dominant position and State aid provisions to airports. In the 1990s, airports in Helsinki, Brussels and Lisbon have been condemned by the EU Commission for preferential treatment of their 'home carriers'. ${ }^{13}$

The question of State aid granted by airports to 'home' or at least 'most preferred' carriers as such carriers are attractive for the commercial presence of the community in which the airport is located in relation to the broader domestic and European landscape, has received attention on the first decade of the 21 st century and is currently being examined by the EU Commission. A landmark decision leading to increased attention for this subject concerned the preferred treatment of Ryanair at the Belgium airport of Charleroi which is located about 80 kilometres South of Brussels. In this case, the EU Commission ruled that financial support and assistance given by the regional authorities in southern Belgium and the Charleroi airport authority to the Irish airline Ryanair constituted, in part, State aid and was unlawful. It ordered that part of the funds received by the airline should be repaid to the authorities concerned. On 17 December 2008, the European Court of Justice annulled the above Commission's decision, as the Commission had not correctly applied the above 'market investor' principle. Among others, the court found that the Commission had wrongly decided that this principle could not be invoked as the aid had been granted by a public authority, namely, the Walloon Region, which did not act as an economic operator. ${ }^{14}$

The topicality of the question of State aid placed in the context of airport-airline relations is illustrated by the establishment of the EU State aid Guidelines which also focus on financing of airports and start up aid to airlines departing from regional airports, ${ }^{15}$ and the case law which is emerging on the subject. European case law is built on the premise that the operation and construction of airport infrastructure cannot deemed to be "a task falling outside the ambit of State aid control." ${ }^{\prime 16}$ The guidelines of 2014 are designed to ensure viable connections between regions and

13 See Commission Decision 1999/198 of 10 February 1999 regarding airport charges at Finnish airports; Commission Decision 95/364/EC of 28 June 1995 regarding landing fees at Brussels airport; Commission Decision 1999/199/EC of 10 February 1999 on landing charges in use at Portuguese airports.

14 See, Ryanair v. Commission, Case T-196/04

15 See: http://www.eipa.nl/UserFiles/File/state_aid/State_Aid_in_the_Transport_Sector.pdf. These Guidelines have been repealed and replaced by a new, substantially different, version, adopted in April 2014 (OJ C 99/3, 04.04.2014).

16 See, Communication from the EU Commission (2013), EU Guidelines on State aid to airports and airlines

G. Burghouwt, et al. — Discussion Paper 2015-04 — C OECD/ITF 2015 
the mobility of European citizens, while minimizing distortions of competition in the internal air transport market ${ }^{17}$

\section{EU external aviation policy: process and impacts}

\section{Establishment of the EU-US agreement on air transport}

\section{Introduction of a market approach towards the operation of the agreed international air services}

As stated in the Progressing Liberalisation section above on the creation of the EU internal market, the traditional air transport regime which was, and still is, governed by bilateral air services agreements (BASAs) concluded between States proceeds from the operation of the agreed international air services by the air carriers which are designated by the two States, Parties to the bilateral agreement. Such an agreement regulates market entry and market behaviour of those designated air carriers, and the level of competition as between them.

Most bilateral air agreements, including the Bermuda-type air services agreements, embraced the view that the designated airlines of the two sides should share the market created under the bilateral agreement, that is, the operation of the agreed international air services, and the capacity equally. In such cases, the designated airline of one side claiming more than 60 per cent of the traffic and capacity in the market violated the 'fair and equal' opportunities laid down in the bilateral agreement. The UK was known for being capable of defining 'fair and equal' in Annex 2 of the Bermuda II Agreement of 1977: the 40/60 split of capacity and frequencies on a gateway to gateway basis was deemed to fall within the confines of 'fair and equal'.

As explained in the Progressing Liberalisation section, the current liberalisation period has been marked by the deregulation process of the internal US market in the late 1970's, the completion of the internal EU air transport market in 1993, and, internationally, by the conclusion of an increasing number of 'Open Skies' agreements, at present more than one hundred. Rules on market entry have been relaxed but not completely abolished. Carriers still have to meet nationality requirements, safety, security environmental and liability standards before they can start flying the agreed international air services. Those standards are intended to be as uniform as possible on a global level, as the Chicago Convention dictates in its Preamble that international air transport services should be stabilised "on the basis of equality of opportunity". However, jurisdictions in the world give different interpretations to the principle of "equality of opportunity" which is regarded as the principal tool for guaranteeing the maintenance of a level playing field internationally. The EU blacklisting regime, the EU Emissions Trade Scheme (ETS), the EU passenger protection rules and the application of strict US based security standards, also outside the US, are liable to affect the global objective of creating uniformity.

Having said that, domestic and international initiatives are designed to introduce a more market oriented approach towards the operation of domestic and international air services. The objective of liberalising the operation of air services is not only practiced in the US, where it all started in 1978 with the deregulation process, and in the EU, with the creation of its internal air transport market - see 
the Creation of the Internal Market section, above - but also in other parts of the world. Notable examples are the arrangements between Australia and New Zeeland in the so-called Tasman Pact, regional initiatives undertaken in Africa, especially in the context of the Common Market for East and South Africa (COMESA), the South African Development Council (SADC) and the East African Community (EAC), the Association South East Nations (ASEAN) and in Latin America (Mercosur and the Andean Pact). Next to these regional initiatives, and, as referred to above, countries all over of the world are concluding 'Open Skies' agreements on a bilateral basis, liberalising market access but especially market behaviour for the designated air carriers.

However, as can be concluded from Annex 4 in which we compare the internal EU regime with a number of other regimes, the EU internal regime is the most advanced international regime in terms of liberalisation.

\section{The EU-US agreement on air transport}

A special if not unique agreement on air transport concerns the EU-US Agreement on air transport, which was signed in 2007, and updated in 2010. The EU-US Agreement, hereinafter also referred to as the Agreement, is essentially an 'Open Skies' type of agreement as it provides for the operation of unlimited third and fourth Freedom rights, that is, in short, the operation of air services between points in the EU and in the US, and vice versa, and also fifth Freedom rights on beyond routes, that is, in short, operations behind or beyond third and fourth Freedom operations, for instance, the right of Air France to pick up traffic in Atlanta, US, with destination Mexico City, on a ParisAtlanta-Mexico City service, for the airlines of each side, with freedom of pricing of the agreed international service. The expression 'Freedoms of the Air' is explained in Annex 1.

The operation of seventh Freedom rights, that is, the right for an EU airline to carry traffic between a point in the US and a point in a third country, and the right for a US airline to operate between a point in the EU and a point in a third country, for instance, the right of United Airlines to carry traffic between Vienna, Austria, and Istanbul Turkey, is more restricted. EU airlines can operate combination passenger services between any point in the US and any point in not only the EU but also the European Common Aviation Area, including Norway, Iceland, Albania and the States that were formerly part of Yugoslavia. Unrestricted seventh Freedom rights for all-cargo services are given to EU airlines, but to US airlines only in respect of services involving a point in one of eight named Member States - the Czech Republic, France, Germany, Luxembourg, Malta, Poland, Portugal and Slovakia.

Most significantly, the US has accepted the 'Community air carrier clause' as it will allow any EU airline, and airlines from the European Economic Area (EEA), including Norway, Iceland and Lichtenstein, to operate between any point in the US and any point in the EU/EEA. EU/EEA airlines are allowed to commence services, and have in fact done so, between points in the US and points in a Member State other than their own ${ }^{18,}$ although the practical relevance of these opportunities has proven to be limited. For commercial reasons, EU air carriers prefer to stick to their traditional hubs, and do not operate 'off line' services. Hence, Air France does not offer flights between Madrid and Miami, Florida, nor does BA offer flights between Helsinki and Boston. The acceptance of the 'Community clause' facilitates cross-border mergers and acquisitions between Community airlines, as the US will no longer be able to threaten to refuse or take away traffic rights on the basis that the carrier is not substantially owned and effectively controlled by the airline's home State and/or its nationals, as explained in the section on the Internal and External Dimensions of the E.U. Carrier Clause.

18 One of the examples are the services of the BA subsidiary Open Skies between The Netherlands (cancelled) and the US and France and the US

G. Burghouwt, et al. — Discussion Paper 2015-04 — @ OECD/ITF 2015 
The availability and allocation of slots at congested airports will continue to be governed by the applicable local rules which is, in the case of the EU, EU Regulation 95/93 as variously amended, and currently (in 2014) under review. As a consequence, although US airlines will have in theory unlimited rights to operate air services from Heathrow, they will only be able to do so in practice if they can acquire slots there through the allocation process or trading.

The Agreement is different from typical BASAs, including open skies agreements, in its provisions for cooperation in a number of areas: security, safety, environment, competition law, State aid and questions of ownership and control, which cooperation is not provided for in 'traditional' bilateral air services agreements. Furthermore, a Joint Committee has been established to resolve questions relating to the interpretation and application of the Agreement, to review its implementation and to facilitate greater cooperation, particularly by consulting on issues dealt with in international organisations and in relations with third countries, including considering whether to adopt a joint approach.

The Agreement can be considered as the most important air services agreement in the world, allowing open market access for air services between the - now - 28 Member States and the US forming a market that together makes up almost 60 percent of global aviation. As said, it created an unprecedented regulatory platform to address all mutual concerns related to EU-US air services. However, differences remain with respect to questions on market access as the EU side wishes to further relax ownership and control conditions for airlines, and to reduce the impact of State aid on the operation of the agreed services. So far the US authorities have resisted these demands although EU carriers gained increased access to US government financed traffic, also referred to as 'Fly America'.

\section{The regulation of competition, including assessment of airline alliances}

Airlines may work together in a less - for instance, in 'naked' code sharing arrangements or arrangements on the use of airport lounges -, or more advanced manner. As to the latter, the next step with respect to cooperative arrangements between airlines regards the formation of airline alliances. The EU Commission has built a wealth of experience in this field. ${ }^{19}$ It distinguishes between product and geographical markets and between business/time sensitive and leisure/price sensitive passengers in relation to the dominance on those markets.

Remedies offered by the parties and approved by the EU Commission may consist of freezing of frequencies on the appearance of a new entrant airline on a certain route, engagements with respect to enter into intermodal arrangements with surface transport operators, for instance, the High Speed Train permitting interlining between air and rail, the grant of fifth freedom traffic rights to other EU air carriers flying to a destination outside the EU and the prohibition pricing on long haul routes. An important measure concerns the rendering of slots. In the British Airways/Iberia/American Airlines case (2010) the EU Commission implicitly opened the door for slot trading, as parties are not prevented from requesting compensation for surrendering slots. ${ }^{20}$ Generally speaking, the EU Commission supports consolidation, with due regard for global developments in this field. Under the regime set forth by EU Regulation 1/2003, the anti-competitive effects of such alliance agreements must now be (self) assessed by airlines. ${ }^{21} 22$

19 See, for instance, Lufthansa/SAS/United Airlines, COMP/D-2/36.201, 36.076 and 36.078 - IP/02/1569 of 29 October 2002; KLM/NorthWest, COMP. 36.111 IP/02/1569 of 29 October 2002

20 British Airways/Iberia/American Airlines - COMP/39569, decision of 14 July 2010

21 The application of EU competition rules in an international context is explained in the Air Freight Cartel cases, as to which see Annex 5 


\section{Merger control}

Merger control is a special issue in international air transport as it bears a close relationship with nationality requirements under which international air transport operates for the purpose of the operation of the agreed international air services under bilateral air services agreements. Moreover, national laws frequently impose restrictions upon the licensing of air carriers on the basis of their nationality, for the EU (see the Progressing Liberalisation section).

Since the adoption of the Merger Regulation (139/2004), the European Commission has reviewed some 30 airline mergers. The first mergers were domestic mergers, followed by a number of international mergers, which have meanwhile been dissolved.

Significant intra-EU cross border merger activities took place in the 21 st century with the merger between Air France and KLM. In Air France/KLM (2004), ${ }^{23}$ the EU Commission found that the airlines' networks were basically complimentary. However, competition would be affected on fourteen European and intercontinental routes on which they currently compete actually or potentially. The parties offered remedies pertaining to the surrender of slots; the freezing of frequencies on the appearance of a new entrant on one of the above routes; the engagement into commitments with surface transport operators, for instance, the High Speed Train between Paris and Amsterdam permitting interlining between air and rail; the grant by Dutch and French governmental authorities of fifth freedom traffic rights to other EU air carriers flying via Amsterdam or Paris to a destination outside the EU, while keeping in mind that those authorities are not allowed to regulate pricing on long haul routes. The US authorities approved the Air France/KLM merger on the same day as the European Commission that is, on 11 February 2004, allowing the combination to go forward. Apart from the EC Commission and the US DoT, a number of countries, including but not limited to Brazil, Japan, Israel, South Africa, the Czech Republic, Poland and Rumania have explicitly approved the deal.

In Lufthansa/Austrian Airlines, ${ }^{24}$ the EU Commission requested the parties to give up slots at specified airports in Germany and Austria, to engage into interline agreements and other arrangements on, for instance access to Frequent Flyer Programmes, with new entrants and into intermodal agreements with surface in carriers, in particular the operators of high speed trains.

22 The Air Cargo Fuel Charges cases have been the first international competition cases in the field of air transport, requiring the application of the provisions prohibiting concerted actions by undertakings (see Article 1010 TFEU). See Annex 5

23 See Prior notification of a proposed concentration which the Commission received on 18 December 2003 pursuant to Art. 4 of Council Regulation 4064/89 (as amended and corrected), OJ C 317/15 (2003). Case No. COMP/M.3280 - Air France/KLM, decision of 11 February 2004, available at: http://europa.eu.int/comm/competition/mergers/cases/decisions/m3280_en.pdf

24 Case M.5440; Decision of 28 August 2009

G. Burghouwt, et al. — Discussion Paper 2015-04 — @ OECD/ITF 2015 
On 14 July 2010, the EU Commission approved the merger between British Airways and Iberia. ${ }^{25}$ The Commission opined that the merged entity would continue to face competition in the various markets, including those for short haul and long haul services, and passenger, cargo and ground handling services.

Remedies used by the European Commission in competition cases include the slot divestiture at congested airports at one of the two or the two O\&D airports. As practice shows that slot divestiture has not always yielded the desired pro-competitive results, the European Commission seems to be willing to adopt a more interventionist role with respect to the implementation of such remedies. Other remedies concern freezing of capacity by the airlines which are subject to competition review; price constraints so as to avoid predatory pricing; introduction of requirements on mandatory engagement into blocked space agreements and interlining with new entrant airlines; access to Frequent Flyer Programmes and Global Distribution Systems (GDS) by new entrant airlines or competitor airlines; relaxation of limitations with respect to the performance of fifth and sixth freedom rights on services from within the EU to points outside the EU and vice versa.

In short, the EU Commission is examining and developing its policy on remedies carefully while assessing their practical effects on the market forces. The approach adopted in merger cases is similar to that adopted in alliances cases.

25 Case M. 5747; Decision of 14 July 2010; see: http://ec.europa.eu/competition/elojade/isef/case_details.cfm?proc_code=2_M_5747 


\section{Conclusions and future perspectives}

\section{Conclusions}

In this paper, we have described the process of the creation and liberalisation of the intra-EU aviation market. By means of a supply-side analysis over an extended period of time (24 years), we have provide -for the first time according to our knowledge- a descriptive analysis of the longer term impacts of EU liberalisation.

In sum, we find that:

During the second half of the 1990s most EU flag carriers were able to establish hub-and-spoke systems at the respective national airports and to increase their share in the intra-EU market. The $2^{\text {nd }}$ package gave them unlimited $3^{\text {rd }}$ and $4^{\text {th }}$ freedom rights to build up their networks. Economic growth and low fuel prices, as well as the then still limited low-cost competition all contributed to favourable market conditions for the 'flag' carriers At the same time, the growth of hub-and-spoke networks during the 1990s, which was still rooted in the old national airport-national airline concept, also resulted in oversupply of hubs in the EU market. All in all, some of these 'flag' carriers struggled with these network transformations and new competition, resulting in substantial State aid actions, until this was blocked by the Commission.

Market conditions for the flag carriers became rapidly less favourable at the end of the 1990s, beginning of 2000s. The economic growth stalled, fuel prices were on the rise and low-cost carrier output was increasing rapidly. A very different competitive arena was the result:

- High growth levels of low-cost carriers, facilitated not only by liberalisation but also by Internet penetration, which allowed them to sell tickets through their online booking websites at a panEuropean scale.

- Flag carriers are under pressure since we observe:

○ Declining intra-EU market shares of the flag carriers since 2000;

- Rise in effective average number of operators at the route level, decrease in the percentage and number of intra-EU routes where flag carriers are the only operator. At the same time, it should be noted that at two thirds of the low-cost carrier routes, the low-cost carrier faces no direct competition. Hence, low-cost carrier growth has for a large part taken place on routes were they face no direct head-to-head competition. These are likely to be lower demand routes. As Dobruszkes (2009) puts it: 'It [Competition] has certainly increased, but much less rapidly than the number of routes operated by a single airline'.

$\circ \quad$ Stagnating aircraft movement growth of the flag carriers;

○ Declining yields;

- Accelerating industry consolidation through mergers, take-overs and bankruptcies among fullservice carriers, stimulated by the new EU state aid policy towards the airlines and absence of US 
chapter 11 options . Consolidation among low-cost carriers still has to start;

- Consolidation and network rationalisation resulted in the loss of hub status for a number of large EU airports during the 1990s.

- It is not unlikely that a further increase in market share of low-cost carriers will be more the result of an increasing cannibalisation of the full-service market share at the hubs instead of a more rapidly growing demand generated on new secondary routes.

Although a consumer welfare impact study is outside the scope of our analysis, it is safe to conclude that the consumer has benefitted from EU liberalisation: number of routes and frequencies has increased substantially since the early 1990s. The rise of hub-networks has improved connectivity both within Europe and between Europe and intercontinental destinations. In addition, there is more choice for the consumer at the route level as well as lower fares, in particular from 2000 onwards. The low-cost revolution created opportunities for smaller airports in the EU airport hierarchy, leading to a more balanced distribution of intra-EU supply over the EU airports and improved accessibility by air of many EU regions.

\section{Future perspectives for the EU market} market:

Based on our results, we foresee the following plausible developments in the EU air transport

Further low-cost carrier growth in a number of EU countries (e.g. Netherlands, France). In other EU countries such as the UK and Ireland, low-cost growth is stagnating and 'organic' growth in line with the economic growth can be expected. Signs of saturation are not in line with fleet orders of the EU lowcost carriers. A scenario of overcapacity in the EU air transport market is not an unlikely.

In response to the saturating market, low-cost carriers will have to alter their network strategies to further expand output and maintain their low unit cost levels. More hybridisation of the low-cost model is likely to take place. Network-wise, this may include the increased use of primary airports, more services on longer routes, more low frequent services and an increase in the cannibalisation of existing routes of flag and regional carriers;

EU (former) flag carriers will be increasingly exposed to low-cost competition on short-haul markets and new hub carrier competition on long-haul markets (Gulf, Turkey). Hence, we may expect:

$\circ \quad$ Further industry consolidation through mergers and take-overs;

○ Bankruptcies of financially weak full-service carriers;

○ Rationalisation and optimisation of hub-networks, de-hubbing of secondary hubs;

- Redefinition of hub-strategies, which may entail the integration of low-cost (subsidiary) carriers into the feeder networks of the full-service carriers in order to reach a lower cost level and to pre-empt competition; for example Vueling and Iberia Express started to contribute to better financial results of Iberia.

Scarcity in large-scale airport capacity will be an increasingly important barrier to entry at Europe's congested airports, undermining the welfare benefits of the liberalised market. Stimulating a transparent secondary market for slots would help to make more efficient use of the existing scarce airport capacity;

Competition at the ground handling market at a number of large EU airports remains limited, despite the new regulation on ground handling; 
Low-cost carrier growth and commercialisation among airports has resulted in more departure airport choice for the consumer and -according to Copenhagen Economics (2012) more competition between airports in the origin-destination market. This trend is likely to be enforced with further growth of lowcost carriers in Europe. Yet, the fact that many airports in Europe in the same geographical region share the same operator/owner limits the full potential for effective airport competition. Breaking-up of airport groups under common ownership in the same geographical region (cf BAA) may create additional competitive constraints to the airports and deliver benefits both to the passenger as well as the airlines;

Unfair competition/ level playing field debates are likely to intensify when business models and worldwide aviation markets further develop, such as the long haul hub and spoke systems operated by the Gulf carriers (De Wit, 2013). See the next section.

\section{Scenarios and challenges regarding market access and competition}

The following scenarios and challenge in terms of market access and competition between airlines may lie ahead of us.

Subject to the remark below on 'fair competition', the EU will continue to export its 'open market with free competition' agenda to third States, and to adjacent States to begin with. The Mediterranean States, and States located in South East Europe, and Eastern Europe will be encouraged to align their aviation policies with those conducted by the EU. In this process the EU Commission has a leading role as it must prepare that alignment and carry out the negotiations. This trend has resulted in the conclusion of Association Agreements between the EU and those States, in which 'regulatory convergence', that is, the approximation of the regulatory approach towards the operation of the agreed international air services coming under those agreements, is a principal target. In practice, alignment means that the non-EU States had to adjust their policies and regulations with those of the EU, not only in the field of market access and the interplay of market forces by competition but also in the areas of safety, security, the environment and consumer protection.

While those surrounding States are willing and prepared to align their policies and laws to those of the EU as their designated air carriers receive access to the attractive EU internal market in return, whereas they can also count on financial and technical assistance from the EU, States in other areas of the world wish to decide their own pace of liberalisation, for domestic policy and commercial reality reasons. One of the principal reasons why the EU-Brazil agreement on air transport, liberalising the market between the two parties along the lines of the EU-US agreement on air transport which has been discussed in the EU-US Agreement on Air Transport section, has not yet been ratified is that Brazilian carriers do not want to lose market share for the benefit of the EU air carriers. The same may be true for the reluctance, so far, of China to sign an air transport agreement with the EU and its Member States. Russia also has political motives for refraining from promoting ties with the EU and the EU Commission.

Absent a global understanding of 'core principles' defining it under the WTO/GATS regime (see below), or any other international regime, the scope of liberalisation of international air transport has yet to be determined. In this process, the introduction of 'fair competition' principles which are concisely addressed in the next point plays a principal role. Based on the Resolutions of the 38th General Assembly of ICAO of 2013, the following ideas on liberalisation are put forward:

$\circ \quad$ Discussion of 'fair competition' principles in the context of competition law regimes (see below);

- Avoidance of conflict between competition law regimes and bilateral air agreements;

$\circ \quad$ ICAO's engagement with the gathering and analysis of competition laws and enforcement actions worldwide;

- Cooperation between competition authorities on a bilateral, regional or multilateral level.

G. Burghouwt, et al. — Discussion Paper 2015-04 — (C) OECD/ITF 2015 
Hence, ICAO appears to support liberalisation by drawing up core principles affecting 'fair competition'. It adopts a more reserved stance with respect to the question of State aid.

Although it does not apply to the operation of air transport services, the WTO regime offers an interesting model in terms of procedures, provisions and measures for liberalisation. The air transport sector takes a special place in trade law as trade in air services are governed by bilateral or plurilateral (e.g., EU-US) agreements in which questions of 'fair competition' and especially State aid have not, not yet or only partially found a place.

A special point on the current and future international air transport agenda concerns the question of 'fair competition' as a result of the invasion of Gulf carriers into markets which were so far dominated by EU and US carriers. Chinese, Indian and South East Asian carriers are also affected by the articulated presence of these Gulf carriers in their respective markets. While the US and the EU, especially the EU States, try to resolve this perceived imbalance in bilateral relationships, the EU Commission, ICAO and other States are working together to promoting standards for 'fair competition' internationally. Various mechanisms are being proposed in order to address this question. They include but are not limited to:

$\circ \quad$ Addressing State aid, which is perceived to be a driver behind the operations of the Gulf carriers, in a bilateral, interregional or global context;

- Including 'fair competition' clauses as formulated by the EU Commission, EU States or ICAO in bilateral air services agreements, or, more generally, international agreements on air transport;

- Requesting more transparency on the financial accounts of the carriers in question before granting traffic rights.

Finally, we believe that regionalism, and regional players, such as the EU, ASEAN, COMESA and other organisations will influence the way in which air services are operated not only on a regional basis but also internationally. Apart from the EU, most regional organisations have a limited mandate only and are commencing their activities in the field of air transport. Moreover, the EU is unique as it has an institutional and constitutional backing giving it its supra-national status under international law, which other regional organisations, which have a more intergovernmental character under international law, lack. Its experience in air transport, trade and competition affairs has greatly helped to shape its policies. However, other organisations are learning their lessons from the EU experiences and will no doubt also inspire the global aviation policy agendas of the next decades. 


\section{References}

Belén Rey, M. (2003). Structural changes in the Spanish scheduled flights market as a result of air transport deregulation in Europe. Journal of Air Transport Management 9(3), 195-200.

Budd, L., G. Francis , Humphreys, I. and S. Ison (2014). Grounded: characterizing the market exit of European low cost airlines. Journal of Air Transport Management 34, 78-85.

Burghouwt, G. and J.G. de Wit (2005). Temporal configurations of European airline networks. Journal of Air Transport Management 11(3), 185-198.

Burghouwt, G. (2007). Airline network development in Europe and its implications for airport planning. Aldershot: Ashgate.

Button, K. (2001). Deregulation and liberalisation of European air transport markets. Innovation: the European Journal of Social Science Research 14(3), 255-275.

CAA (1995). The single European aviation market: the progress so far. London: Civil Aviation Authority.

CAA (1998). The single European aviation market: the first five years. London: Civil Aviation Authority.

De Wit, J.G. and J. Zuidberg (2012). The growth limits of the low cost carrier model. Journal of Air Transport Management 21, 17-23.

De Wit, J.G. (2013). An Unlevel Playing Field? Ah yes, you mean protectionism. Journal of Air Transport Management, dx.doi.org/j.airtraman.2013.11.012

Dobruszkes, F. (2009). Does liberalisation of air transport imply increasing competition? Lessons from the European case. Transport Policy 29-39.

Dobruzskes, F. (2013). The geography of European low-cost airline networks: a contemporary analysis. Journal of Transport Geography, 75-88.

Doganis, R. (1973). Air Transport: A Case Study in International Regulation. Journal of Transport Economics and Policy, May 1973.

Doganis, R. (1994). The impact of liberalisation on European airline strategies and operations. Journal of Air Transport Management 1(1), 15-25.

Eurocontrol (2013). Challenges for growth. Task 6: the effect of air traffic network congestion in 2035.

Graham, B. (1998). Liberalisation, regional economic development and the geography for air transport in the European Union. Journal of Transport Geography 6(2), 87-104.

Gudmundson, S.V. (2014). Mergers vs alliances. The Air France-KLM story. Available at SSRN: http://ssrn.com/abstract=2142915 or http://dx.doi.org/10.2139/ssrn.2142915

Kerns, C., D. Paukova and F. Schlapbach (2009). The battle for the European leisure traveler. Can the charter airline business model survive. Available at: http://www.ottimo.ch/fd/files/charters.pdf 
Klophaus, R., R. Conrady and F. Fichert (2012). Low cost carriers going hybrid: evidence from Europe. Journal of Air Transport Management 23, 54-58.

Leigh, R. (2014). Stimulation effects wear off. Available at http://www.aviationeconomics.com/NewsItem.aspx?title=Low-cost-airlines:-Stimulation-effects-wearoff\&utm_source=AVEC-Mailing-List-20-Jun\&utm_medium=email\&utm_campaign=AVEC-MailingList, 20 June 2014

Morrell, P. (1998). Air transport liberalisation in Europe: the progress so far. Journal of Air Transportation World-wide 3(1), 42-61.

Morrison, S.A. \& C. Winston (1995). The evolution of the airline industry. Washington: The Brookings Institution.

Morrison, S.A. (2001). Actual, adjacent and potential competition: estimating the full effect of Southwest Airlines. Journal of Transport Economics and Policy 35(2), 239-356.

Redondi, R., P. Malighetti and S. Paleari (2012). De-hubbing of airports and their recovery patterns. Journal of Air Transport Management 18(1), 1-4.

Burghouwt, G. and R. Redondi (2013). Connectivity in air transport networks: an assessment of models and applications. Journal of Transport Economics and Policy 47(1), 35-53.

Reynolds-Feighan, A.J. (1995). European and American approaches to air transport liberalisation: some implications for small communities. Transportation Research Part A: Policy and Practice 29(6), 467-483.

Thompson, I.B. (2002). Air transport liberalisation and the development of third level airports in France. Journal of Transport Geography 10(4), 273-285.

Williams, G. (1994). The airline industry and the impact of deregulation. Aldershot: Ashgate.

Williams, G. (2002). Airline competition: deregulation's mixed legacy. Aldershot: Ashgate. 


\title{
Annex 1. Freedoms of the air
}

\author{
First Freedom: \\ To overfly one country en-route to another \\ Ex.: Aerolinas Argentinas flies over Brazil from Buenos Aires to Chicago (US)

\section{Second Freedom:} \\ To make a technical stop in another country \\ Ex.: Aeroflot makes a stop for fuelling purposes in Warsaw (Poland) on a flight between Moscow and London
}

\section{Third Freedom}

The carriage of traffic (passengers and cargo) from the home country of the airline to another country

Ex.: Air France carries traffic from Paris to Minneapolis (US)

\section{Fourth Freedom}

The carriage of traffic to the home country from another country

Ex.: Garuda (Indonesia) carries traffic from New Delhi to Jakarta

\section{Fifth Freedom}

The carriage of traffic between two foreign countries by an airline of a third country, which carriage is linked with third and fourth Freedom traffic rights of the airline.

Ex.: Japan Airlines operates a service originating in Tokyo to Mexico City, and then on to New York, picking up traffic in Mexico City with destination New York

\section{Sixth Freedom}

The carriage of fifth Freedom traffic between two foreign countries via the home country of the airline

Ex.: Emirates (UAE) carries traffic originating in Katmandu (Nepal) via Dubai (UAE) to Nairobi

\section{Seventh Freedom}

The carriage of traffic between two foreign countries by an airline of a third country, which carriage is not linked with third and fourth Freedom traffic rights of the airline.

Ex.: South African Airways carries traffic between Cairo (Egypt) and Rome (Italy) on a service, which is unrelated to a point in South Africa

\section{Eighth Freedom}

The carriage of passengers and cargo between two points in a foreign country on a route with origin and/or destination in the home country of the airline.

Ex.: TAP (Portugal) carries traffic between Sao Paolo and Brasilia (both in Brazil), on a flight Lisbon - Sao Paolo Brasilia

\section{Ninth Freedom}

The carriage of passengers and cargo between two points in a foreign country on a route, which is unrelated to the home country of the airline.

Ex.: SAS (Scandinavia) carries traffic between Madrid and Barcelona (both in Spain) on a service which is unrelated to a point in Scandinavia. 


\section{Annex 2. Low-cost airlines and years of operation as applied in this paper}

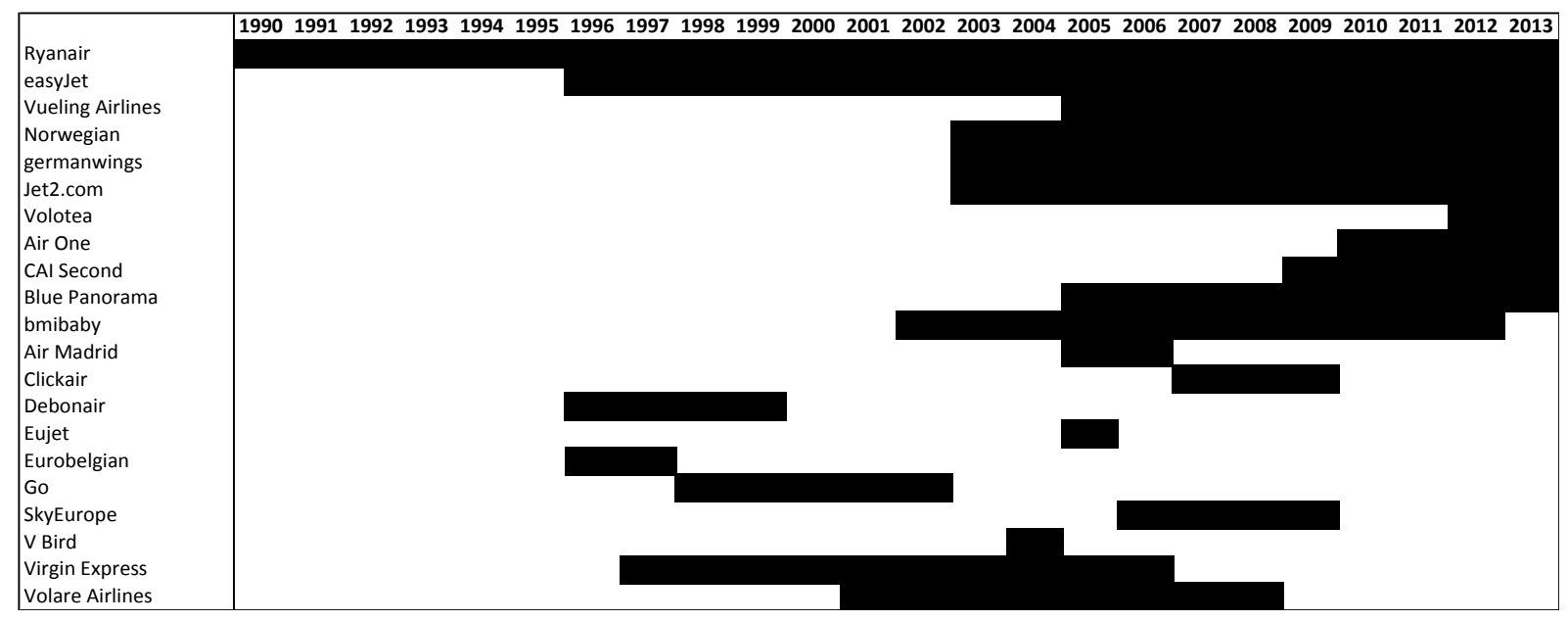




\section{Annex 3. Low-cost carriers in different studies}

\begin{tabular}{|c|c|c|c|c|c|}
\hline European Airline & CAPA & Budd et al. & Klophaus & Dobruszkes & Burghouwt et al \\
\hline Intersky & & $X$ & & & $X$ \\
\hline Germanwings & $x$ & $x$ & $x$ & $x$ & $x$ \\
\hline Flybe & $X$ & & $x$ & $X$ & \\
\hline Dba & & $x$ & & $x$ & \\
\hline Norwegian & $x$ & $x$ & $x$ & $x$ & $x$ \\
\hline Alpi Eagles & & & & $x$ & \\
\hline Aer Lingus & & & $X$ & $x$ & \\
\hline Ryanair & $X$ & $x$ & $x$ & $x$ & $x$ \\
\hline Wind Jet & & $X$ & $x$ & $x$ & \\
\hline Jet2.com & $X$ & $x$ & $x$ & $x$ & $X$ \\
\hline Sterling & & $X$ & & $X$ & \\
\hline Sky Europe & & $X$ & & $x$ & $X$ \\
\hline Air Finland & & & & $x$ & \\
\hline Skynet Airlines & & & & $x$ & \\
\hline Germania (Express) & & $x$ & & $x$ & \\
\hline Transavia.com France & $X$ & & & $x$ & \\
\hline Virgin Express & & $x$ & & $x$ & $X$ \\
\hline easyJet & $X$ & $x$ & $x$ & $x$ & $x$ \\
\hline Volare Airlines & $x$ & $x$ & & $x$ & $x$ \\
\hline Vueling Airlines & $X$ & $x$ & $x$ & $x$ & $x$ \\
\hline MyTravelLite & & $x$ & & $x$ & \\
\hline Wizz Air & $X$ & $X$ & $X$ & $x$ & 26 \\
\hline Wizz air Ukraine & $x$ & & & $x$ & \\
\hline Wizz air Bulgaria & $x$ & & & & \\
\hline Bmibaby & & $x$ & $x$ & $x$ & $x$ \\
\hline Hapa-Lloyd Express & & & & $x$ & \\
\hline Monarch Airlines & $x$ & & & $x$ & \\
\hline airberlin & & $X$ & $x$ & & \\
\hline Meridiana fly & & & $x$ & & \\
\hline Air Baltic & $x$ & & $x$ & & \\
\hline Transavia & $x$ & $x$ & $x$ & & \\
\hline $\mathrm{NIKI}$ & $x$ & & $x$ & & \\
\hline Blu Express & $x$ & & $x$ & & \\
\hline Corendon & & & $x$ & & \\
\hline Blue Air & $x$ & & $x$ & & \\
\hline Air Italy & & & $x$ & & \\
\hline
\end{tabular}

26 Wizz Air not considered because no intra-EU15+2 flights were reported during the period of analysis. 


\begin{tabular}{|c|c|c|c|c|c|}
\hline European Airline & CAPA & Budd et al. & Klophaus & Dobruszkes & Burghouwt et al \\
\hline Arkefly & $x$ & & & & \\
\hline EasyJet Switzerland & $x$ & & & & \\
\hline Feel Air & $x$ & & & & \\
\hline Iberia Express & $x$ & & & & \\
\hline Islas Afortunadas Air & $X$ & & & & \\
\hline Jetairfly & $x$ & & & & \\
\hline Smart Wings & $x$ & & & & \\
\hline Sun Express Germany & $x$ & & & & \\
\hline TUlfly & $x$ & & & & \\
\hline Volotea & $x$ & & & & $x$ \\
\hline Air One & & & & $x$ & \\
\hline CAI Second & & & & & $x$ \\
\hline Blue Panorama & & & & $x$ & \\
\hline Air Madrid & & & & & $x$ \\
\hline Eurobelgian & & & & & $x$ \\
\hline WOW air & $x$ & $x$ & & & \\
\hline Air Polonia & & $x$ & & & \\
\hline Air Scotland & & $x$ & & & \\
\hline Air Turquoise & & $x$ & & & \\
\hline Basiq Air & & $x$ & & & \\
\hline Buzz & & $x$ & & & \\
\hline Central Wings & & $x$ & & & \\
\hline Click Air & & $x$ & & & $x$ \\
\hline Color Air & & $x$ & & & \\
\hline Debonair & & $\mathrm{x}$ & & & $x$ \\
\hline EU Jet & & $x$ & & & $x$ \\
\hline Fly Globespan & & $x$ & & & \\
\hline Flying Finn & & $x$ & & & \\
\hline FlyMe & & $x$ & & & \\
\hline FlyNordic & & $x$ & & & \\
\hline Get Fly & & $x$ & & & \\
\hline Go & & $x$ & & & $x$ \\
\hline Goodjet & & $x$ & & & \\
\hline $\mathrm{HLX}$ & & $x$ & & & \\
\hline My Air & & $x$ & & & \\
\hline Snowflake & & $x$ & & & \\
\hline Star 1 & & $x$ & & & \\
\hline Thomsonfly.com & & $x$ & & & \\
\hline V Bird & & $x$ & & & $x$ \\
\hline Zoom UK & & $x$ & & & \\
\hline
\end{tabular}




\section{Annex 4. \\ Comparison between bilateral and plurilateral arrangements governing the operation of international air services}

The table below compares provisions of bilateral air services agreements on the economic operation of international air services bilateral air services with those laid down in regional arrangements, and Open Skies agreements. The table illustrates these provisions in an eye bird's view only as the freedoms listed there are conditioned in the relevant arrangements whereas the relationship between regional arrangements and the underlying bilateral air services concluded between the members of the regional organisations must be assessed on a case by case basis. The Freedoms of the Air, identifying the degree of market access granted to the eligible air carriers, are explained in Annex 1. The higher the Freedom number (IX), and the greater the number of Freedoms of the Air granted to the relevant air carriers, the higher the degree of liberalisation.

Comparison of the degree of liberalisation of selected air policy regimes

\begin{tabular}{|c|c|c|c|c|c|c|}
\hline & $\begin{array}{l}\text { Traditional } \\
\text { bilateral } \\
\text { agreements }\end{array}$ & Andean Pact & ASEAN & COMESA & $\begin{array}{l}\text { Open } \\
\text { Skies }\end{array}$ & $\begin{array}{l}\text { EU internal } \\
\text { market }\end{array}$ \\
\hline $\begin{array}{l}\text { Nationality } \\
\text { requirements } \\
\text { for airlines } \\
\text { (O\&C) }\end{array}$ & Applicable & $\begin{array}{l}\text { Principal place of } \\
\text { business in a } \\
\text { member state }\end{array}$ & $\begin{array}{l}\text { ASEAN nationals and } \\
\text { principal place of } \\
\text { business in ASEAN State } \\
\text { (cf. EU) }\end{array}$ & Applicable & Applicable & $\begin{array}{c}\text { EU } \\
\text { requirements }{ }^{27}\end{array}$ \\
\hline Designation & Single or dual & Multiple & Multiple & Multiple & Multiple & Unlimited 28 \\
\hline Traffic rights ${ }^{29}$ & I-IV & $\begin{array}{l}\text { I-V, subject to } \\
\text { conditions }\end{array}$ & $\begin{array}{l}\text { I-VI, subject to } \\
\text { conditions, other } \\
\text { Freedoms to be } \\
\text { implemented }\end{array}$ & $\begin{array}{l}\text { I - IV, V subject } \\
\text { to conditions }\end{array}$ & $\begin{array}{c}\text { I-VI } \\
\text { (passengers) or } \\
\text { I-VII (cargo) }\end{array}$ & $I-I X$ \\
\hline Pricing ${ }^{30}$ & $\begin{array}{l}\text { Subject to } \\
\text { conditions }\end{array}$ & $\begin{array}{l}\text { Country of origin } \\
\text { approval }\end{array}$ & Free & $\begin{array}{l}\text { Progressive } \\
\text { liberalisation }\end{array}$ & Free & Free \\
\hline Capacity & $\begin{array}{l}\text { Subject to } \\
\text { conditions }\end{array}$ & No restrictions & No restrictions & No restrictions & No restrictions & No restrictions \\
\hline Frequencies & $\begin{array}{l}\text { Subject to } \\
\text { conditions }\end{array}$ & No restrictions & No restrictions & $\begin{array}{c}\text { Pax services } \\
\text { restricted; } \\
\text { No restrictions for } \\
\text { cargo and charter }\end{array}$ & No restrictions & No restrictions \\
\hline $\begin{array}{l}\text { Applicability of } \\
\text { competition } \\
\text { law regime }\end{array}$ & $\begin{array}{l}\text { Not relevant: } \\
\text { ex ante } \\
\text { economic } \\
\text { regulation }\end{array}$ & $\begin{array}{l}\text { No reference to } \\
\text { competition law } \\
\text { regime }\end{array}$ & $\begin{array}{l}\text { No reference to } \\
\text { competition law regime }\end{array}$ & COMESA regime & $\begin{array}{l}\text { US regime; } \\
\text { application of } \\
\text { positive comity }\end{array}$ & EU regime \\
\hline
\end{tabular}

27 Including that nationality of airlines operating under EU Regulation 1008/2008 are "substantially owned" (more than $50 \%$ ) and "effectively controlled" by nationals of the EU, and have their principal place of business in a Member State of the EU.

28 The term "designation" does not apply to the regime set forth by the EU; access to intra-Community routes is free for Community airlines if the conditions drawn up by EU Regulation 1008/2008 are satisfied.

29 In terms of Freedoms of the Air; see Annex 1.

30 Free pricing is subject to government interventions in cases of predatory or discriminatory pricing, and, in the case of intra-EU traffic, to the EU Commission's supervisory tasks under Regulation 1008/2008. 


\section{Explanation of Terms:}

Nationality requirements for airlines: for airlines to access an international air transport market they must have a nationality which is expressed in terms of ownership (nationality of the shareholders) and control (nationality of the members of the airline's executive board), in short: O \& C. Most bilateral air service agreements provide that airlines operating the agreed international air services must be "substantially owned and effectively controlled" by the state or nationals of the state designating (as to which see the next term) the airline for the operation of the agreed international air services.

Designation: States party to a bilateral agreement can agree to designate one, two or multiple airlines complying with the agreed nationality requirements as to which see the previous term - for the operation of the (agreed) international air services.

Traffic rights - Traditional bilateral air services agreement tend to focus on the operation of third and fourth Freedoms of the Air providing basic market access opportunities for the designated airlines; see also Annex $\ldots$ of this report.

Pricing: encompasses pricing of the agreed international air services. Fares refer to passenger services whereas rates are related to cargo services. Variations exist as to the freedom of air carriers to set fares. Traditional bilateral air services agreements regulate pricing quite strictly, giving governments, often represented by Civil Aviation Authorities, the authority to control pricing of the agreed international air services.

Capacity: the volume of traffic in terms of passenger seats or cargo space that is available for the operation of the agreed international air services.

Frequencies refer to the number of air services per week which a designated airline is allowed to operate under the terms of the bilateral air services agreement.

Applicability of competition law regimes: as governments through traditional bilateral air services agreements regulate and control international air transport markets ex ante as exemplified by the above provisions, there is no room for the application of competition regimes. However, Open Skies agreements liberalise international air transport markets facilitating the introduction of competition regimes.

The EU applies, or at least has a regulatory framework in place for applying, its competition law regime to the operation of international air services, and is the only jurisdiction regulating, and in applicable cases, forbidding State aid, and applying the freedom of establishment to the air transport sector, while allowing the operation of external services from any establishment, or hub, in the EU to points outside the EU. For instance, when Lufthansa has an establishment in Rome, it is entitled, pursuant to EU law, to operate air services from there to Jakarta in Indonesia. Whether the Indonesian authorities would agree with such operations is another question. 


\section{Annex 5.}

\section{The Air Cargo Fuel Charge cases}

The Air Cargo Fuel Charges cases have been the first international competition cases in the field of air transport, requiring the application of the provisions prohibiting concerted actions by undertakings (see Article 1010 TFEU). The investigation started in 2006 with dawn raids, also involving non-EU airlines. On 9 November 2010, the EU Commission imposed fines of almost 800 million $€$ on eleven airlines for operating a cartel on cargo fuel and security charges. ${ }^{31}$ Hence, concerted behaviour by way of price fixing has been punished severely; pricing must be made in an independent fashion. The EU Commission warned that "the existence of an alliance agreement cannot give a blank cheque for naked price coordination among the members." On the other side, the Commission showed comprehension for the existence of the regulatory regime prevailing in international air transport encouraging in some cases airline to behave in an anti-competitive manner because of government dictated trade in air services as illustrated by the mentioned bilateral air services agreements; this comprehension resulted in some cases to a $15 \%$ reduction of fines. All airlines apart from Qantas airlines appealed the decision. Moreover, airline managers who have been involved with these cases have undergone imprisonment, especially in the US and the UK which apply criminal sanctions to natural persons committing cartel offenses.

Also, the US Department of Justice has conducted criminal price fixing investigations of certain airlines. The investigation resulted in 17 guilty pleas and over 1.6 US\$ billion in fines to date, the largest fines ever imposed in a single criminal antitrust investigation. 
